\title{
Tropical troposphere to stratosphere transport of carbon monoxide and long-lived trace species in the Chemical Lagrangian Model of the Stratosphere (CLaMS)
}

\author{
R. Pommrich ${ }^{1,2,3}$, R. Müller ${ }^{1}$, J.-U. Grooß ${ }^{1}$, P. Konopka ${ }^{1}$, F. Ploeger ${ }^{1}$, B. Vogel $^{1}$, M. Tao ${ }^{1}$, C. M. Hoppe ${ }^{1}$, G. Günther ${ }^{1}$, \\ N. Spelten ${ }^{1}$, L. Hoffmann ${ }^{4}$, H.-C. Pumphrey ${ }^{5}$, S. Viciani ${ }^{6}$, F. D’Amato ${ }^{6}$, C. M. Volk ${ }^{7}$, P. Hoor ${ }^{8}$, H. Schlager ${ }^{9}$, and \\ M. Riese ${ }^{1}$ \\ ${ }^{1}$ IEK-7, Forschungszentrum Jülich, Jülich, Germany \\ ${ }^{2}$ Laboratoire d'Aérologie, UMR5560, CNRS/INSU-Université de Toulouse 3, 14 Av Edouard Belin, 31400 Toulouse, France \\ ${ }^{3}$ Groupe d'étude de l'Atmosphère Météorologique, URA 1357, CNRM-GAME, Météo-France, 42 Av Gaspard Coriolis, \\ 31057 Toulouse CEDEX 1, France \\ ${ }^{4}$ JSC, Forschungszentrum Jülich, Jülich, Germany \\ ${ }^{5}$ School of GeoSciences, University of Edinburgh, Edinburgh, UK \\ ${ }^{6}$ CNR-Istituto Nazionale di Ottica (CNR-INO), L. go E. Fermi 6, 50125 Florence, Italy \\ ${ }^{7}$ Bergische Universität Wuppertal, Wuppertal, Germany \\ ${ }^{8}$ Johannes-Gutenberg Universität Mainz, Mainz, Germany \\ ${ }^{9}$ Deutsches Zentrum für Luft- und Raumfahrt, Institut für Physik der Atmosphäre, Oberpfaffenhofen, Germany
}

Correspondence to: R. Müller (ro.mueller@fz-juelich.de)

Received: 18 July 2014 - Published in Geosci. Model Dev. Discuss.: 8 August 2014

Revised: 27 October 2014 - Accepted: 30 October 2014 - Published: 8 December 2014

\begin{abstract}
Variations in the mixing ratio of trace gases of tropospheric origin entering the stratosphere in the tropics are of interest for assessing both troposphere to stratosphere transport fluxes in the tropics and the impact of these transport fluxes on the composition of the tropical lower stratosphere. Anomaly patterns of carbon monoxide (CO) and long-lived tracers in the lower tropical stratosphere allow conclusions about the rate and the variability of tropical upwelling to be drawn. Here, we present a simplified chemistry scheme for the Chemical Lagrangian Model of the Stratosphere (CLaMS) for the simulation, at comparatively low numerical cost, of $\mathrm{CO}$, ozone, and long-lived trace substances $\left(\mathrm{CH}_{4}, \mathrm{~N}_{2} \mathrm{O}, \mathrm{CCl}_{3} \mathrm{~F}\right.$ (CFC-11), $\mathrm{CCl}_{2} \mathrm{~F}_{2}(\mathrm{CFC}-12)$, and $\left.\mathrm{CO}_{2}\right)$ in the lower tropical stratosphere. For the long-lived trace substances, the boundary conditions at the surface are prescribed based on ground-based measurements in the lowest model level. The boundary condition for $\mathrm{CO}$ in the lower troposphere (below about $4 \mathrm{~km}$ ) is deduced from MOPITT measurements. Due to the lack of a specific representation of mixing and convective uplift in the troposphere in this
\end{abstract}

model version, enhanced $\mathrm{CO}$ values, in particular those resulting from convective outflow are underestimated. However, in the tropical tropopause layer and the lower tropical stratosphere, there is relatively good agreement of simulated $\mathrm{CO}$ with in situ measurements (with the exception of the TROCCINOX campaign, where $\mathrm{CO}$ in the simulation is biased low $\approx 10-15$ ppbv). Further, the model results (and therefore also the ERA-Interim winds, on which the transport in the model is based) are of sufficient quality to describe large scale anomaly patterns of $\mathrm{CO}$ in the lower stratosphere. In particular, the zonally averaged tropical $\mathrm{CO}$ anomaly patterns (the so called "tape recorder" patterns) simulated by this model version of CLaMS are in good agreement with observations, although the simulations show a too rapid upwelling compared to observations as a consequence of the overestimated vertical velocities in the ERA-Interim reanalysis data set. Moreover, the simulated tropical anomaly patterns of $\mathrm{N}_{2} \mathrm{O}$ are in good agreement with observations. In the simulations, anomaly patterns of $\mathrm{CH}_{4}$ and $\mathrm{CFC}-11$ were found to be very similar to those of $\mathrm{N}_{2} \mathrm{O}$; for all long-lived 
tracers, positive anomalies are simulated because of the enhanced tropical upwelling in the easterly shear phase of the quasi-biennial oscillation.

\section{Introduction}

Carbon monoxide ( $\mathrm{CO}$ ) has sources at the Earth's surface mostly from incomplete combustion of fossil fuels and from biomass burning. $\mathrm{CO}$ is also chemically produced in the troposphere by the oxidation of methane and non-methane hydrocarbons and is removed from the atmosphere by oxidation with $\mathrm{OH}$, leading to a lifetime of about two months in the troposphere (e.g. Pfister et al., 2004); the lifetime in the stratosphere is somewhat longer (a few months, e.g. Hoor et al., 2004; Schoeberl et al., 2006). Because of the relatively long tropospheric lifetime of $\mathrm{CO}, \mathrm{CO}$ concentrations in the troposphere are strongly influenced by transport processes. Thus, CO is useful as an indicator of long-range transport of polluted air masses. As a result of the low background mixing ratios of $\mathrm{CO}$ in the lower stratosphere $(\approx 20-40 \mathrm{ppbv})$, $\mathrm{CO}$ is an important tracer of troposphere to stratosphere transport, during strong convective activity (Ricaud et al., 2007; Srivastava and Sheel, 2013), within rapidly ascending airstreams, so-called warm conveyor belts, in extratropical cyclones (Roiger et al., 2011), within the Asian monsoon circulation (Park et al., 2007, 2008, 2009; Liu et al., 2013; Vogel et al., 2014), and during slow ascent and mixing in the lowermost tropical stratosphere (Konopka et al., 2007; Schoeberl et al., 2006; Fueglistaler et al., 2009; Homan et al., 2010; Abalos et al., 2012; Ploeger et al., 2012a). Moreover, it has been observed that the seasonal variation in the mixing ratio of $\mathrm{CO}$ entering the stratosphere at the bottom of the tropical tropopause layer (TTL) is carried upward with the rising air in the tropics with the signal being observable throughout the tropical lower stratosphere (Schoeberl et al., 2006; Randel et al., 2007; Liu et al., 2007; Pumphrey et al., 2008; Liu et al., 2013). This phenomenon is commonly referred to as the "atmospheric tape recorder" (Mote et al., 1996). Annual and quasi-biennial oscillation (QBO) driven variations in the strength of the Brewer-Dobson circulation have an impact on the tape recorder pattern (Nivano et al., 2003; Randel et al., 2007; Schoeberl et al., 2008). There are also observations of sub-seasonal variations in $\mathrm{CO}$ in the tropical lower stratosphere that have recently been linked with sub-seasonal variations in tropical upwelling (Abalos et al., 2012). Therefore, the seasonal variation in the mixing ratio of species like water vapour, $\mathrm{CO}$, and $\mathrm{HCN}$ in the lower tropical stratosphere provides information on the rate of tropical upwelling in this region, a quantity which is important, but relatively poorly constrained in meteorological analyses (e.g. Ploeger et al., 2011; Diallo et al., 2012; Liu et al., 2013; Wright and Fueglistaler, 2013; Randel and Jensen, 2013).
Robust anomaly patterns in the tropical stratosphere have also been reported for $\mathrm{CCl}_{3} \mathrm{~F}$ (CFC-11), $\mathrm{CCl}_{2} \mathrm{~F}_{2}$ (CFC-12), $\mathrm{N}_{2} \mathrm{O}$, and $\mathrm{CH}_{4}$ based on satellite measurements (Randel et al., 1998; Schoeberl et al., 2008; Kellmann et al., 2012; Khosrawi et al., 2013). $\mathrm{CCl}_{3} \mathrm{~F}, \mathrm{CCl}_{2} \mathrm{~F}_{2}, \mathrm{~N}_{2} \mathrm{O}$, and $\mathrm{CH}_{4}$ are trace gases with purely tropospheric sources and with very long stratospheric lifetimes, ranging between about 50 years and more than 100 years (e.g. Volk et al., 1997; Brown et al., 2013; Minschwaner et al., 2013; Ko et al., 2013; Hoffmann et al., 2014). These trace gases do not exhibit a strong seasonal (or more irregular) variability in the lowermost tropical stratosphere and thus do not show a pronounced tape recorder pattern like water vapour, $\mathrm{CO}$, and $\mathrm{HCN}$. Nonetheless, in the lower tropical stratosphere, where mixing ratios of these trace gases are only moderately reduced compared to tropospheric values, a weak tape recorder signal for $\mathrm{N}_{2} \mathrm{O}$ and $\mathrm{CH}_{4}$ is detectable because of annual variations in the vertical velocity (Schoeberl et al., 2008). Further, variability in tropical upwelling induced by the QBO (Baldwin et al., 2001; Ribera et al., 2004; Punge et al., 2009; Flury et al., 2013), acting on the stronger vertical trace gas gradient in the tropical stratosphere at altitudes above $\approx 500 \mathrm{~K}(55 \mathrm{hPa}$, $20 \mathrm{~km}$ ), induces more pronounced anomaly patterns in longlived trace species like $\mathrm{CCl}_{3} \mathrm{~F}, \mathrm{~N}_{2} \mathrm{O}$, and $\mathrm{CH}_{4}$ (Randel et al., 1998; Schoeberl et al., 2008; Kellmann et al., 2012; Khosrawi et al., 2013).

Here, we describe an extension of the Chemical Lagrangian Model of the Stratosphere (CLaMS) (McKenna et al., 2002b, a; Grooß et al., 2005; Konopka et al., 2004, 2007) that allows multi-annual simulations of CO, ozone, long-lived tracers, and age of air in the tropical upper troposphere and lower stratosphere to be made for investigations of phenomena like the atmospheric tape recorder in $\mathrm{CO}$ or anomaly patterns in long-lived trace species. CLaMS studies have originally focused on investigations of polar stratospheric chemical ozone loss (e.g. McKenna et al., 2002a; Grooß et al., 2002; Konopka et al., 2004; Grooß and Müller, 2007), but the model was extended later to the analysis of transport processes in the tropopause region, both in the extratropics (Pan et al., 2006; Vogel et al., 2011; Konopka and Pan, 2012; Spang et al., 2014) and in the tropics (Konopka et al., 2007, 2010; Ploeger et al., 2013). This version of CLaMS was also successfully applied to describe the irregular tape recorder pattern discovered for HCN (Pumphrey et al., 2008; Pommrich et al., 2010). Here, we will focus on anomaly patterns of $\mathrm{CO}$ and long-lived trace species in the tropics to assess the quality of transport and chemistry simulations in this version of CLaMS.

The model concept used here is different from chemical models of the stratosphere and troposphere that employ a comprehensive description of the tropospheric chemistry and a wide range of emissions of trace substances at the ground (e.g. Jöckel et al., 2006; Schultz et al., 2008; Boynard et al., 2012; Morgenstern et al., 2009, 2013; Kumar et al., 2013; Srivastava and Sheel, 2013). Such mod- 
els require a detailed and numerically expensive description of tropospheric chemistry and the impact of surface emissions on tropospheric CO. In contrast, we make use of $\mathrm{CO}$ measurements from the Measurements of Pollution in the Troposphere (MOPITT) satellite experiment (Deeter et al., 2003) in version 4 (Deeter et al., 2010) for formulating a lower boundary condition for $\mathrm{CO}$ for multi-annual simulations of upper tropospheric and lower stratospheric transport of $\mathrm{CO}$ in the tropics. Together with a simplified chemistry scheme (with pre-calculated and tabulated radical concentrations) this concept allows successful simulations of $\mathrm{CO}$ in the lower tropical stratosphere to be made at comparatively low numerical cost. In addition to $\mathrm{CO}$, the simplified scheme allows the simulation of the long-lived species $\mathrm{CH}_{4}$, $\mathrm{N}_{2} \mathrm{O}, \mathrm{CCl}_{3} \mathrm{~F}, \mathrm{CCl}_{2} \mathrm{~F}_{2}$, and $\mathrm{CO}_{2}$. In this way, the unique Lagrangian transport scheme of CLaMS, which is inherently non-diffusive and therefore particularly well suited for the simulation of strong trace gas gradients (e.g. McKenna et al., 2002b; Konopka et al., 2005), may be applied to studies of the upper troposphere and lowermost stratosphere. An alternative concept for a numerically efficient simulation of $\mathrm{CO}$ in the stratosphere, based on a representation of transport by trajectories and pre-calculated chemical tendencies from a chemical climate model has been recently presented by Wang et al. (2014).

Here we present simulations of CO using the CLaMS chemical transport model driven by ERA-Interim meteorological fields (Dee et al., 2011) over the time period from January 2005 to the end of October 2012 for the tropical lower stratosphere and compare the results with both remotesensing and in situ measurements. The simplified chemistry scheme described here was recently used for studying the implementation of the CLaMS Lagrangian transport core into the chemistry climate model EMAC (Hoppe et al., 2014). (A preliminary account of the work presented here, based of MOPITT version 3 data (Deeter et al., 2003) and ECMWF operational analyses was given earlier by Pommrich et al., 2011).

The version of CLaMS presented here will allow addressing a variety of current research questions, which require an accurate and efficient representation of transport and chemical processes in the vicinity of the tropical and extratropical tropopause. Transport processes in this region are frequently problematic to simulate, because of strong gradients in trace species (e.g. $\mathrm{CO}, \mathrm{H}_{2} \mathrm{O}, \mathrm{HCN}, \mathrm{O}_{3}$ ). Examples for such research questions are transport pathways through the Asian monsoon, intrusions of upper tropospheric tropical air masses into the lowermost extratropical stratosphere and of small scale (e.g. warm conveyor belts) transport pathways from the troposphere to the stratosphere.

The paper is structured as follows. We first present the remote-sensing and in situ measurements of tropical $\mathrm{CO}$ which we use, then we describe the model system, namely the transport and the simplified chemistry scheme, as well as the upper and lower boundary conditions. In Sect. 4, we show the model results in comparison with both in situ and remote-sensing measurements and discuss our findings. Section 5 contains our conclusions.

\section{Measurements of $\mathrm{CO}$ in the upper troposphere and lower stratosphere}

We use several sources for tropical CO data, both for prescribing boundary conditions for a multi-annual CLaMS simulation and for evaluating the results of the simulation (see Sects. 3.3 and 4 below). We use remote-sensing measurements from the MOPITT instrument, a nadir-looking satellite experiment (Deeter et al., 2003) and from the microwave limb sounder (MLS), a microwave limb viewing instrument (Waters et al., 2006). Further, we use in situ $\mathrm{CO}$ measurements onboard the high-flying research aircraft Geophysica from the cryogenically operated laser diode (COLD) spectrometer (Viciani et al., 2008) and from the gas-chromatography measurements by the HAGAR (highaltitude gas analyzer) instrument (Volk et al., 2000; Homan et al., 2010). Finally, we consider in situ CO measurements in the upper troposphere onboard a Learjet by the tunable diode laser absorption spectrometer (TDLAS) TRISTAR (tracer in situ TDLAS for atmospheric research) (Hoor et al., 2004).

The MOPITT remote sensing instrument was launched aboard the EOS Terra satellite on 18 December 1999; routine measurements began in March 2000. Terra is in a sunsynchronous orbit with $705 \mathrm{~km}$ average altitude, 99 min period, and $98^{\circ}$ inclination. The equator crossing of the ascending nodes takes place at about $10.30 \mathrm{a} . \mathrm{m}$. MOPITT views the Earth over all latitudes with a ground pixel size of $22 \mathrm{~km} \times 22 \mathrm{~km}$ and a cross-track swath of $640 \mathrm{~km}$ that provides a near-global measurement of the distribution of $\mathrm{CO}$ every three days. Operational MOPITT CO products in version 4 are based on $4.7 \mu \mathrm{m}$ thermal-channel radiances (Deeter et al., 2010). The information content in MOPITT retrievals is quantified through the degrees of freedom for signal which indicates the number of independent pieces of information in the retrieved profile (Deeter et al., 2004). In the tropics and in the mid-latitudes, the value for the degrees of freedom for signal is in general greater than one, which implies that MOPITT measurements provide some profile shape information, while a value of the degrees of freedom for signal of 1 indicates that the profile contains no more information than the column. The maximum sensitivity to the true atmospheric state is located around $\sim 5 \mathrm{~km}$ altitude or $500 \mathrm{hPa}$ pressure (Deeter et al., 2003). Here we use the level 2 data of the version 4 retrievals of MOPITT, which are validated extensively (e.g. Emmons et al., 2004, 2007, 2009; Luo et al., 2007; Deeter et al., 2010, and references therein). More recently, version 5 (Deeter et al., 2011) and version 6 (only for 2008) of MOPITT CO data were released.

MLS is an instrument on the EOS Aura satellite, which was launched on 15 July 2004. The EOS Aura satellite flies 
in a near polar, sun-synchronous orbit (in the "A Train" satellite constellation) at $98^{\circ}$ inclination with a period of approximately $100 \mathrm{~min}$ and at an altitude of about $705 \mathrm{~km}$ above the Earth. The equatorial crossing time is about 1.45 p.m. MLS views the Earth's limb in the orbit plane of the Aura spacecraft. Observations range from $82^{\circ} \mathrm{S}$ to $82^{\circ} \mathrm{N}$ every day and are spaced $140 \mathrm{~km}$ apart along the ground track. MLS detects thermally emitted radiation in several bands of the millimetre and sub-millimetre spectral region yielding profiles of temperature, geopotential height and the volume mixing ratio of several chemical species. The mixing ratio of $\mathrm{CO}$ is obtained from measurements of the spectral line at $230 \mathrm{GHz}$. Here we use version 3.3 retrievals. The vertical resolution of MLS CO measurements is in the range $3.5-5 \mathrm{~km}$ from the upper troposphere to the lower mesosphere. The MLS retrieval technique is described in detail by Livesey et al. (2006) and the validation of the MLS CO data product (in version 2.2) is described by Pumphrey et al. (2007) and Livesey et al. (2008).

The COLD spectrometer is a tunable diode laser (TDL) instrument designed for operation on a high-altitude aircraft for the measurement of CO (Viciani et al., 2008). The absolute in-flight accuracy for $\mathrm{CO}$ is $6-9 \%$. The precision is given by the value of either $1 \%$ of the mixing ratio or $7-$ $8 \mathrm{ppbv}$, depending on which value is larger. The time resolution of the data is $4 \mathrm{~s}$ which corresponds to a horizontal resolution of about $800 \mathrm{~m}$ for an average airplane cruising speed of $750 \mathrm{~km} \mathrm{~h}^{-1}$ (Viciani et al., 2008).

The tunable diode laser absorption spectrometer TRISTAR (Hoor et al., 2004) is an instrument for measurements of $\mathrm{CO}$ on research aircraft. It measures $\mathrm{CO}$ with a temporal resolution of $5 \mathrm{~s}$ at $1.5 \mathrm{~s}$ integration time for each data point. The instrument is in situ calibrated against secondary standards of compressed ambient air, which have been traced against primary standards from NOAA/CMDL prior to and after the measurement campaigns. The total uncertainty for $\mathrm{CO}$ based on the reproducibility of the in-flight calibrations is better than $1.5 \%$ relative to the secondary standards (typically $100-150 \mathrm{ppbv})$.

HAGAR (Volk et al., 2000; Homan et al., 2010) is a multitracer in situ instrument that, apart from $\mathrm{CO}$, also provides simultaneous in situ measurements of $\mathrm{CO}_{2}$ and a suite of long-lived tracers, namely $\mathrm{CH}_{4}, \mathrm{~N}_{2} \mathrm{O}, \mathrm{CFC}-12$, CFC- $11, \mathrm{H}-$ $1211, \mathrm{SF}_{6}$ and $\mathrm{H}_{2}$. Except for $\mathrm{CO}_{2}$, which is measured at high time resolution ( 3 to $5 \mathrm{~s}$ ) by non-dispersive infrared absorption (NDIR), all the other species were measured by gas chromatography with electron capture detection (GC/ECD) every $110 \mathrm{~s}$. The detection of $\mathrm{CO}$ (as well as $\mathrm{CH}_{4}$ and $\mathrm{H}_{2}$ ) is achieved by adding about $25 \mathrm{ppmv}$ of $\mathrm{N}_{2} \mathrm{O}$ to the detector (Phillips et al., 1979). Frequent calibrations were performed in flight (usually every $9 \mathrm{~min}$ ) using two secondary standards with mixing ratios of $138 \mathrm{ppb}$ and $68 \mathrm{ppb}( \pm 7 \%)$. Although the precision based on the reproducibility of in-flight calibrations was mostly better than $7 \mathrm{ppb}$, the total uncertainty of HAGAR's CO measurements during TROCCINOX was dominated by an estimated $\sim 10 \mathrm{ppb}$ systematic error due to a significant non-linearity of detector response to $\mathrm{CO}$ that could not be accurately characterised for flight conditions. The CO measurement was hampered by two other problems. First, after starting the instrument, satisfactory sensitivity to $\mathrm{CO}$ was established only gradually, such that reliable CO data are only available after the first flight hour. Second, for air samples with ozone mixing ratio exceeding $\sim 260 \mathrm{ppb}$ the measurement was significantly biased by $\mathrm{CO}$ released from heated steel tubing inside HAGAR, which caused the loss of most stratospheric $\mathrm{CO}$ data above $400 \mathrm{~K}$.

\section{The Chemical Lagrangian Model of the Stratosphere (CLaMS)}

\subsection{CLaMS transport}

CLaMS is a chemical transport model designed to simulate chemistry, advection, and mixing in the stratosphere and upper troposphere (McKenna et al., 2002a, b; Konopka et al., 2007, 2010). CLaMS is based on a Lagrangian representation of transport, with the intensity of mixing in the model transport being driven by the strength of flow deformation. Thus, the model should be particularly well suited for the simulation of tracer transport in the vicinity of strong transport barriers and the associated tracer gradients.

The model employs a hybrid coordinate $(\zeta)$, which transforms from a strictly isentropic coordinate $\theta$ to a $\sigma$ coordinate system below a certain reference level $\sigma_{\mathrm{r}}=0.3$, where $\sigma=p / p_{\mathrm{s}}$, with $p_{\mathrm{s}}$ denoting the surface pressure (Mahowald et al., 2002). Thus, $\sigma_{\mathrm{r}}=0.3$ corresponds to about $300 \mathrm{hPa}$ over sea level. Over orography, $\sigma_{\mathrm{r}}=0.3$ corresponds to lower pressures; the most extreme case would be the summit of Mt. Everest $\left(p_{\mathrm{s}} \approx 330 \mathrm{hPa}\right)$ where $\sigma_{\mathrm{r}}=0.3$ corresponds to about $100 \mathrm{hPa}$. The hybrid coordinate $\zeta$ is defined as

$$
\zeta(p)=f(\sigma) \cdot \theta(p, T(p)), \quad \sigma=\frac{p}{p_{\mathrm{s}}}
$$

with

$$
f(\sigma)= \begin{cases}\sin \left(\frac{\pi}{2} \frac{1-\sigma}{1-\sigma_{\mathrm{r}}}\right) & \sigma>\sigma_{\mathrm{r}} \\ 1 & \sigma \leq \sigma_{\mathrm{r}}, \quad \sigma_{\mathrm{r}}=0.3 .\end{cases}
$$

The use of this coordinate allows the tropospheric upwelling, as it is represented in the pressure tendencies $(\dot{p}=$ $\omega)$ of the ECMWF ERA-Interim reanalysis, to be represented in the CLaMS transport (see Konopka et al., 2007, for details). However, a parametrisation of subgrid-scale convectively driven vertical transport, as it is present for example in the ECMWF model, is not included in this model version of CLaMS. Further, the CLaMS mixing scheme was designed originally for describing stratospheric transport (McKenna et al., 2002b; Konopka et al., 2004, 2005) and thus there are only limited tests of its application to tropospheric transport (Vogel et al., 2011). In order to obtain mass-conserving ve- 
locity fields on an annual scale the calculated vertical velocities $\dot{\zeta}$ are corrected (Rosenlof, 1995; Konopka et al., 2010) so that zonally and annually averaged total mass fluxes vanish across each $\zeta(\phi)$ surface (with $\phi$ being latitude).

The specific model setup employed here follows closely the setup described by Konopka et al. (2007, 2010), with orography following lower boundary conditions (Riese et al., 2012). The mean horizontal resolution is $100 \mathrm{~km}$ and the mean vertical resolution in the tropopause region about $400 \mathrm{~m}$. Multi-annual, global CLaMS simulations of the whole troposphere and stratosphere (from the ground up to the stratopause around $2500 \mathrm{~K}$ potential temperature, (corresponding to $\approx 60 \mathrm{~km}, 0.2 \mathrm{hPa}$ ) cover the time period from January 2005 to the end of October 2012.

To define the Lagrangian air parcels, the concept of an entropy- and static stability-based grid is applied as described by Konopka et al. (2012, see Figs. 3 and 4). Interpolation within such a grid mimics physical mixing only if both the vertical and the horizontal resolution properly scales with the vertical coordinate. This approach generalises the procedure described earlier (Konopka et al., 2007), where the atmosphere was divided into an irregular grid of air parcels with a variable thickness, but with the same (mean) horizontal distance between the air parcels. Thus, in the previous procedure (Konopka et al., 2007), although the vertical resolution qualitatively renders the true atmospheric vertical diffusivity (e.g. with smaller vertical separation in the stratosphere than in the troposphere), the horizontal resolution is the same for all air parcels throughout the model domain.

The procedure described by Konopka et al. (2012) overcomes this disadvantage by using physical assumptions to define both the vertical and the horizontal resolution of a full Lagrangian grid, namely same entropy per air parcel and aspect ratio of every air parcel derived from the static stability, (for details see Konopka et al., 2012, the resulting improvements in the model simulations are discussed briefly in the Supplement).

\subsection{Simplified chemistry scheme}

The CLaMS model contains a comprehensive stratospheric chemistry scheme including catalytic ozone loss cycles and heterogeneous chemistry at the surfaces of stratospheric aerosol particles and polar stratospheric clouds (e.g. McKenna et al., 2002a; Grooß and Müller, 2007; Grooß et al., 2011; Wegner et al., 2012; Grooß et al., 2014). Here, the focus is on a limited set of trace species in the TTL, in particular on $\mathrm{CO}$, but also on $\mathrm{N}_{2} \mathrm{O}, \mathrm{CH}_{4}, \mathrm{CCl}_{3} \mathrm{~F}$ (CFC11), $\mathrm{CCl}_{2} \mathrm{~F}_{2}$ (CFC-12), $\mathrm{O}_{3}$, and $\mathrm{CO}_{2}$ from which information about advection and mixing in the TTL can be deduced. A strongly simplified chemistry is implemented in this model version, which is designed to describe reasonably well the first order chemical loss of long-lived tracers, production of ozone and its chemical loss in the lower stratosphere, as well as the production and loss of stratospheric CO. There are five long-lived tracers considered in the simplified chemistry scheme, namely $\mathrm{CH}_{4}, \mathrm{~N}_{2} \mathrm{O}, \mathrm{CCl}_{3} \mathrm{~F}, \mathrm{CCl}_{2} \mathrm{~F}_{2}$, and $\mathrm{CO}_{2}$. Ploeger et al. $\left(2011,2012 \mathrm{~b}\right.$ ) showed that the $\mathrm{O}_{3}$ budget in the upper TTL and lower stratosphere is well represented employing this simplified chemistry scheme. The parametrised reactions that constitute the simplified scheme are designed to represent the net result of reaction cycles and, therefore, cannot be written in a way that is stoichiometrically correct. For example, in Reaction (R4), the initial reaction product of the methane oxidation by $\mathrm{Cl}$ is $\mathrm{HCl}$, however the ultimate product of the hydrogen atoms in the methane molecule in the stratosphere is two $\mathrm{H}_{2} \mathrm{O}$ molecules. Products other than $\mathrm{CO}, \mathrm{O}_{3}, \mathrm{CO}_{2}$, and $\mathrm{H}_{2} \mathrm{O}$ are ignored in this approach. The parametrised reactions implemented in the model are

$$
\begin{aligned}
& \mathrm{CO}+\mathrm{OH} \rightarrow \mathrm{CO}_{2}+\text { products } \\
& \mathrm{CH}_{4}+\mathrm{OH} \rightarrow 2 \mathrm{H}_{2} \mathrm{O}+\mathrm{CO}+\text { products } \\
& \mathrm{CH}_{4}+\mathrm{O}\left({ }^{1} \mathrm{D}\right) \rightarrow 2 \mathrm{H}_{2} \mathrm{O}+\mathrm{CO}+\text { products } \\
& \mathrm{CH}_{4}+\mathrm{Cl} \rightarrow 2 \mathrm{H}_{2} \mathrm{O}+\mathrm{CO}+\text { products } \\
& \mathrm{N}_{2} \mathrm{O}+\mathrm{O}\left({ }^{1} \mathrm{D}\right) \rightarrow \text { products } \\
& \mathrm{N}_{2} \mathrm{O}+h v \rightarrow \text { products } \\
& \mathrm{CCl}_{3} \mathrm{~F}+h v \rightarrow \text { products } \\
& \mathrm{CCl}_{2} \mathrm{~F}_{2}+h v \rightarrow \text { products } \\
& \mathrm{O}_{2}+h v\left(+2 \mathrm{O}_{2}\right) \rightarrow 2 \mathrm{O}_{3} \\
& {\left[\mathrm{O}_{3}+\mathrm{OH} \rightarrow \mathrm{HO}_{2}+\mathrm{O}_{2}\right] \times 0} \\
& {\left[\mathrm{O}_{3}+\mathrm{HO}_{2} \rightarrow \mathrm{OH}+2 \mathrm{O}_{2}\right] \times 2 .}
\end{aligned}
$$

Most rate constants are taken from the recommendations in Sander et al. (2011). (For the model runs shown here, exceptions are Reactions (R3) and (R5), for which rates are taken from Sander et al. (2006) and Reaction (R1), for which the rate is taken from Sander et al. (2002)). The photolysis rates were calculated as diurnal averages using the CLaMS photolysis code (Becker et al., 2000). Reaction (R11) constitutes the rate limiting step of the $\mathrm{HO}_{\mathrm{x}}$ catalytic ozone loss cycle (Reactions R10-R11) in which two ozone molecules are destroyed $\left(2 \mathrm{O}_{3} \rightarrow 3 \mathrm{O}_{2}\right)$. Thus, Reaction (R11) is assigned twice the recommended value to represent the ozone loss through this cycle and in turn, the rate of Reaction (R10) is set to zero. By this approach and by accounting for photochemical production of ozone through the photolysis of molecular oxygen (Reaction R9), the most important reactions that determine ozone concentrations in the lowermost stratosphere are represented in the model.

The concentrations of the radicals $\mathrm{Cl}, \mathrm{O}\left({ }^{1} \mathrm{D}\right), \mathrm{OH}$, and $\mathrm{HO}_{2}$ are prescribed as tabulated, monthly average, values as a function of latitude and pressure level for each month. Concentrations of methane and ozone are taken from the HALOE climatology (Grooß and Russell, 2005) and the radical concentrations are then calculated from a simulation of the box model version of CLaMS including the complete chemistry scheme (McKenna et al., 2002b; Grooß and Müller, 2007) for each pressure level and latitude over a months period. These 
tabulated climatologies of $\mathrm{Cl}$ (for 2005 conditions), $\mathrm{O}\left({ }^{1} \mathrm{D}\right)$, $\mathrm{OH}$, and $\mathrm{HO}_{2}$ are available as a Supplement of this paper.

The reduction of the numerical cost from the full stratospheric chemistry (Grooß et al., 2014) to the simplified chemistry presented here was estimated for the example of a CLaMS simulation with about 370000 air parcels employing both 4 and 128 numerical cores. The numerical cost of the chemistry module was reduced by a factor of 33 and 12 , respectively. This corresponds to a reduction of the numerical cost of the entire simulation by a factor of 17 and 2.7, respectively.

\subsection{Boundary conditions for $\mathrm{CO}$ and long-lived tracers at the top and bottom of the model domain}

The model setup presented here is aimed at using $\mathrm{CO}$ as a tracer of tropospheric air transported into the TTL, rather than investigating $\mathrm{CO}$ in the lower troposphere and the detailed impact of local tropospheric sources. Furthermore, we intend to implement a background $\mathrm{CO}$ field rather than an accurate representation of extreme values of tropical $\mathrm{CO}$, e.g. as caused by rapid convective transport from source regions in the boundary layer. Therefore, $\mathrm{CO}$ is prescribed in the lower troposphere at model levels at and below $\zeta=200 \mathrm{~K}$ (i.e. below about $4 \mathrm{~km}$ ) based on measurements. Here, we use MOPITT measurements at $500 \mathrm{hPa}$, where MOPITT CO is most reliable (Deeter et al., 2004; Emmons et al., 2004). However, because of the rather wide averaging kernels of MOPITT (Fig. 1 in Deeter et al., 2004), the MOPITT values reported at $500 \mathrm{hPa}$ are influenced by the $\mathrm{CO}$ values in a thicker layer $(\sim 200-700 \mathrm{hPa} ; 3-12 \mathrm{~km})$ in the troposphere.

The CO measurements by MOPITT do not cover the boundary layer, where tropospheric $\mathrm{CO}$ concentrations are highest (e.g. Boynard et al., 2012; Kumar et al., 2013). MOPITT only reaches global coverage after three days and, in addition, the density of measurements is often limited by cloud occurrence. Therefore, we calculate trajectories using the CLaMS trajectory module and based on ERA-Interim winds from the MOPITT measurement locations during a 5day period, forward and backward, to 12:00 UTC on the central day of the 5-day period. The data are binned into a $2^{\circ} \times 6^{\circ}$ latitude/longitude grid and then averaged on each grid point location weighted by the distance to the corresponding grid point location to construct the boundary condition for the central day. The MOPITT CO field constructed in this way is then interpolated onto the model levels in $\zeta$-coordinates. An example of the so-derived $\mathrm{CO}$ field on a regular grid for northern hemisphere winter and summer conditions at $\zeta=200 \mathrm{~K}(\approx 3-4 \mathrm{~km})$ is shown in Fig. 1. Next, the model levels at and below $\zeta=200 \mathrm{~K}$ are set to the $\mathrm{CO}$ values of the $\zeta=200 \mathrm{~K}$ level. The spatial resolution of MOPITT and the processing described above allows some of the spatial variability of $\mathrm{CO}$ to be captured, albeit not at the scale of smaller scale convective events (Fig. 1). Further, due to the averaging procedure, the high and low extremes in $\mathrm{CO}$ in the measure-

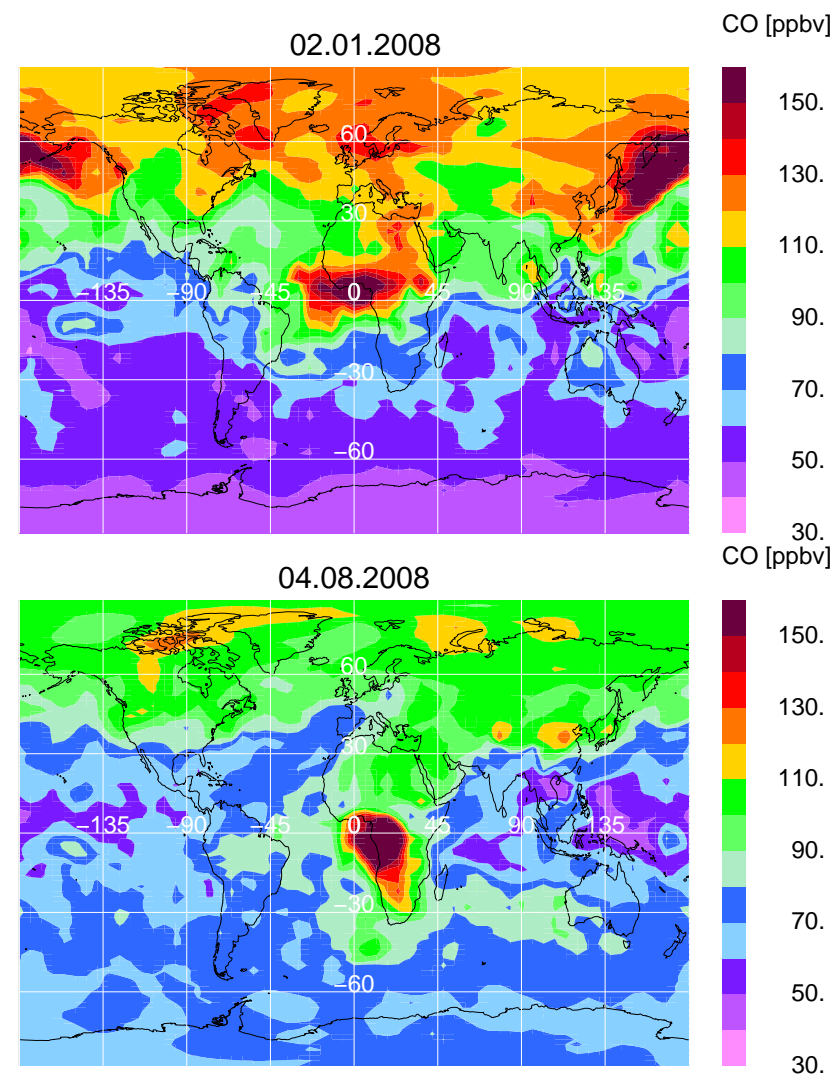

Figure 1. Mixing ratios of $\mathrm{CO}$ on the $\zeta=200 \mathrm{~K}$ model level $(\approx 3-$ $4 \mathrm{~km}$ ) on 2 January 2008 (top panel) and 4 August 2008 (bottom panel), as derived from five days of MOPITT (version 4) measurements through a trajectory technique. (See text for details).

ments will be smoothed. This is also noticeable clearly in Fig. 6 below.

The tropospheric CO fields deduced in this way, however, underestimate the enhanced $\mathrm{CO}$ values in the boundary layer, below about 1-2 km, (e.g. Boynard et al., 2012; Kumar et al., 2013) and thus the CO total column in the lower troposphere. Therefore, the $\mathrm{CO}$ values prescribed at the lower boundary condition below the $\zeta=200 \mathrm{~K}$ level are scaled up by a factor to correct for the underestimation of $\mathrm{CO}$ in the lowermost troposphere. The factor can be adjusted for the particular question being addressed; in the model simulations discussed here, a factor of 2 was applied in order to allow the impact of rapid uplift on $\mathrm{CO}$ concentrations in the upper troposphere to be described (see also discussion below). It is also possible to use other satellite measurements of $\mathrm{CO}$ than MOPITT for constructing the boundary for $\mathrm{CO}$ in the troposphere. For example, Vogel et al. (2011) used AIRS (atmospheric infrared sounder) CO measurements (Aumann et al., 2003) to prescribe the CO boundary condition in the lowest model layer in a case study of transport of $\mathrm{CO}$ and other trace gases in a tropopause fold in the free troposphere. At 
the upper boundary $(\theta=2500 \mathrm{~K}), \mathrm{CO}$ is set according to the Mainz-2D model (Grooß, 1996).

For the long-lived tracers $\mathrm{CO}_{2}, \mathrm{CH}_{4}, \mathrm{CCl}_{3} \mathrm{~F}, \mathrm{CCl}_{2} \mathrm{~F}_{2}$, and $\mathrm{N}_{2} \mathrm{O}$ boundary conditions are prescribed as mixing ratios in the lowest model level. For $\mathrm{CO}_{2}$ and $\mathrm{CH}_{4}$ the measurements from the NOAA/CMDL ground-based measurement network are used (Masarie and Tans, 1995; Novelli et al., 2003) ${ }^{1}$. An alternative data source for prescribing $\mathrm{CH}_{4}$ at the lower boundary is the AIRS instrument (which provides also information on $\mathrm{CO}$, Vogel et al., 2011). $\mathrm{CCl}_{3} \mathrm{~F}, \mathrm{CCl}_{2} \mathrm{~F}_{2}$, and $\mathrm{N}_{2} \mathrm{O}$ are derived from the in situ measurements from CATS instruments (CATS-chromatograph for atmospheric trace species) being in continuous operation at six NOAA baseline observatories since 1999 (e.g. Montzka et al., 1996; Rigby et al., 2013) ${ }^{2}$. Like for $\mathrm{CO}_{2}$ and $\mathrm{CH}_{4}$ a zonally symmetric lower boundary condition is derived. At the upper boundary $\mathrm{CCl}_{3} \mathrm{~F}$ and $\mathrm{CCl}_{2} \mathrm{~F}_{2}$ are set to zero, whereas the HALOE climatology (Grooß and Russell, 2005) is used for $\mathrm{CH}_{4}$ and $\mathrm{N}_{2} \mathrm{O}$.

In addition, for the interpretation of the data and for the definition of the upper boundary of $\mathrm{CO}_{2}$, the mean age $\Gamma(\lambda, \phi, \zeta)(\lambda$, longitude; $\phi$, latitude; $\zeta$, vertical coordinate) is used. The mean age $\Gamma$ is determined by considering a strictly linearly increasing artificial tracer in the boundary layer. $\Gamma$ is calculated as the time lag, at a given time, between the stratospheric tracer value and the tracer value in the boundary layer (Waugh and Hall, 2002). The mean age of air $(\Gamma)$ at $\zeta=2500 \mathrm{~K}$ is estimated from MIPAS observations of $\mathrm{SF}_{6}$ (Stiller et al., 2008). Because no corrections for mesospheric $\mathrm{SF}_{6}$ losses are included, this so-called "apparent" mean age is probably somewhat too high, although possible differences, caused by mesospheric contributions, are difficult to quantify.

The upper boundary of $\mathrm{CO}_{2}$ at time $t$, latitude $\phi$, and longitude $\lambda$, is defined through $\mathrm{CO}_{2}(\lambda, \phi, t)=\left\langle\mathrm{CO}_{2}\right\rangle(t-$ $\Gamma(\lambda, \phi, \zeta=2500 \mathrm{~K}))$, where $\left\langle\mathrm{CO}_{2}\right\rangle$ denotes the mean value of $\mathrm{CO}_{2}$ in the tropics (zonally averaged in the latitude range $\pm 30^{\circ}$ ) calculated from the NOAA/CMDL groundbased measurement network. Thus, at the upper boundary, $\mathrm{CO}_{2}$ is derived from the $\mathrm{CO}_{2}$ distribution in the tropical boundary layer that was observed in the past, where the time lag is quantified in terms of the mean age. Because the apparent age used at the upper boundary is probably somewhat too high, the $\mathrm{CO}_{2}$ values at this level are probably somewhat too low. This deficiency will be more relevant at high latitudes, where air is descending, than in the tropics, where the influence of the upper boundary on the composition of the atmosphere and thus on the age of air estimates is limited.

Because tropospheric ozone is not a focus of the simulations shown here, the volume mixing ratio of ozone at the surface is set to zero, between the surface and $\theta=500 \mathrm{~K}$

\footnotetext{
${ }^{1}$ See http://www.esrl.noaa.gov/gmd/ccgg/globalview/ch4/ch4_ intro.html, http://www.esrl.noaa.gov/gmd/ccgg/globalview/co2/ co2_intro.html

${ }^{2}$ See http://www.esrl.noaa.gov/gmd/hats/insitu/cats/
}

$(\approx 20 \mathrm{~km}, 55 \mathrm{hPa})$ the volume mixing ratio of ozone is calculated based on the simplified chemistry scheme described above (Sect. 3.2), and above $\theta=500 \mathrm{~K}$ ozone is prescribed from the HALOE climatology (Grooß and Russell, 2005).

\section{Comparison of simulated CO with MLS measurements}

We first compare the simulated monthly climatology of the $\mathrm{CO}$ anomaly pattern for summer and winter in the lower stratosphere at $390 \mathrm{~K}$ with MLS measurements (Fig. 2). This anomaly was calculated for both the measurements and the results of the simulation by subtracting the monthly mean $\mathrm{CO}$ mixing ratio $\langle\mathrm{CO}\rangle$ at $390 \mathrm{~K}$ from the monthly mean $\mathrm{CO}$ mixing ratio $\operatorname{CO}(\lambda, \phi)$ at each grid point and then calculating the monthly anomaly pattern, as $100 \cdot(\mathrm{CO}(\lambda, \phi)-\langle\mathrm{CO}\rangle) /\langle\mathrm{CO}\rangle$. The monthly anomaly patterns at $390 \mathrm{~K}$ are then averaged for winter (DJF) and summer (JJA) for the entire time period (2005-2012) resulting in the climatology shown in Fig. 2. The CLaMS model results were convoluted with the MLS averaging kernels (Livesey et al., 2011) for each single profile to allow a better comparison.

The main feature of the anomaly pattern is well reproduced, namely enhanced values in the tropics compared to mid-latitudes and high latitudes in both summer and winter. The anomaly in mid-latitudes in the summer hemispheres is well represented, however, compared to MLS, the model clearly overestimates the anomaly fields in the winter hemisphere at mid-latitudes. The reason for this discrepancy is unclear at this point in time. Another pronounced anomaly feature, which is well reproduced in the model is the positive $\mathrm{CO}$ anomaly over the region of the Asian summer monsoon (JJA). Further, the lower anomaly values in the summer season, both at $\approx 30-40^{\circ} \mathrm{S}$ in the South Pacific (in DJF, Fig. 2, top left panel) and in the North Atlantic at $\approx 30-40^{\circ} \mathrm{N}$ (in JJA, Fig. 2, bottom left panel) are reproduced in the simulation. Very similar results for a comparison of results of a trajectory model with MLS observations at $68 \mathrm{hPa}(\approx 20 \mathrm{~km})$ between $\pm 45^{\circ}$ was recently reported by Wang et al. (2014).

An important test for the ability of a model to describe transport and chemistry of longer lived tropospheric tracers like $\mathrm{CO}$ in the tropical upper troposphere and lower stratosphere is the temporal development of anomaly signals in the air ascending in the tropics, commonly referred to as "atmospheric tape recorder" (Mote et al., 1996; Schoeberl et al., 2006). For a successful reproduction of the $\mathrm{CO}$ tape recorder pattern, a model needs to be able to describe correctly the seasonality of $\mathrm{CO}$ in the upper troposphere and the transport within the troposphere to the bottom of the TTL, where the seasonal CO pattern is imprinted on the ascending air (or where, in other words, the "tape head is located"). Further, the model needs to be driven with appropriate vertical velocities for the upward transport in the tropical lower stratosphere without the anomaly pattern being destroyed by an 

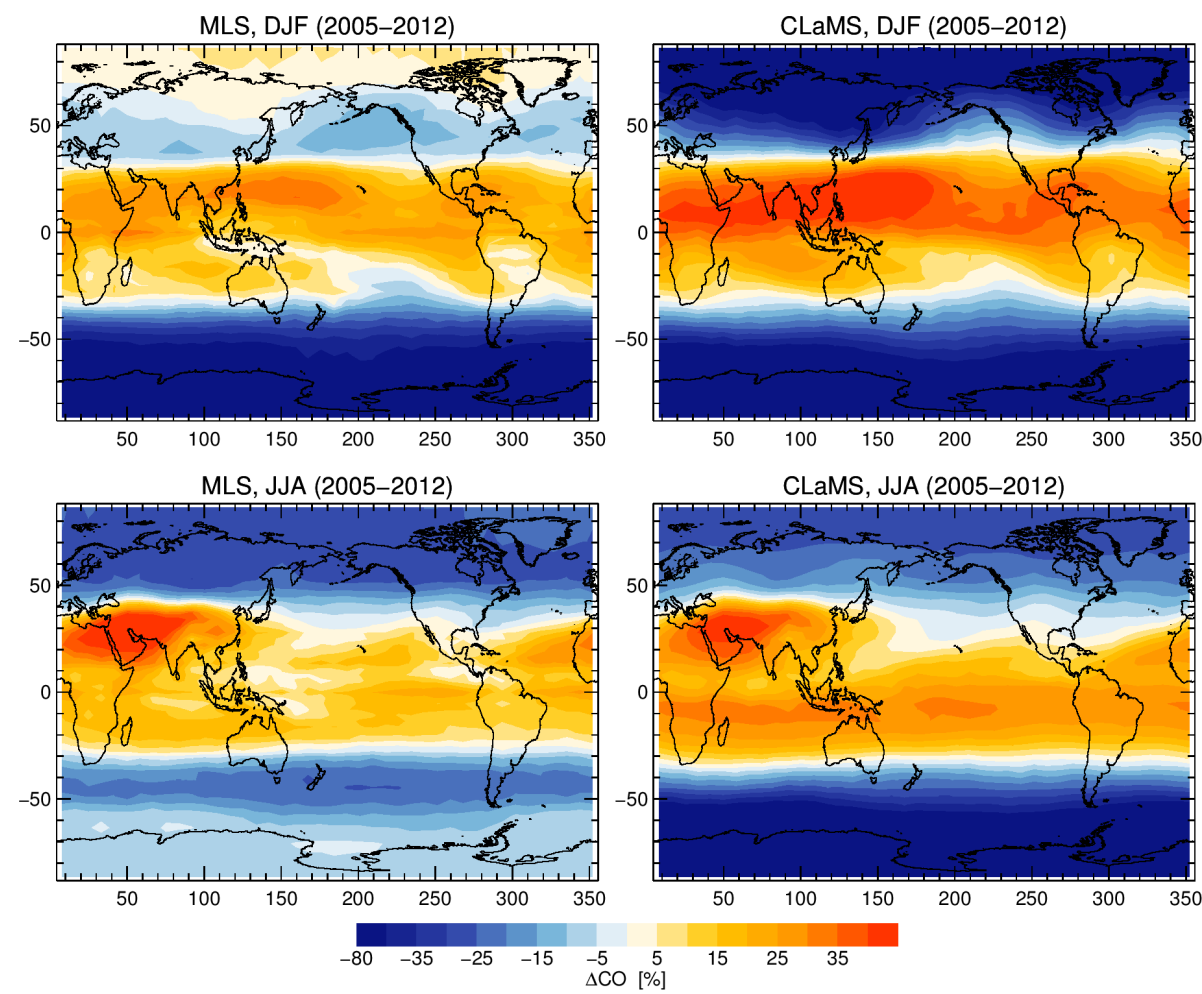

Figure 2. Comparison of the climatological anomalies of the CLaMS simulations with MLS measurements at the $390 \mathrm{~K}$ potential temperature surface. CLaMS CO values were interpolated on the locations of the MLS measurements and vertically smoothed with the MLS averaging kernels. For both measured (left hand panels) and simulated (right hand panels) CO values the climatological anomaly (with respect to the mean value at the $390 \mathrm{~K}$ potential temperature level) for the time period 1 January 2005 to 31 October 2012 is shown (see text for details). Top panels show northern hemisphere winter (DJF) conditions, bottom panels show northern hemisphere summer (JJA) conditions. (Note that the largest bin for negative anomalies ranges from -80 to $-40 \%$ because the negative anomalies reach rather large values).

excessive vertical or horizontal diffusion or incorrect chemistry. Finally, the extent of horizontal in-mixing into the TTL, which affects tape recorder patterns (Konopka et al., 2010; Ploeger et al., 2012a) needs to be correctly described.

In Fig. 3, the simulated (seasonal) anomaly pattern of tropical, zonally averaged $\mathrm{CO}$, i.e. the $\mathrm{CO}$ "tape recorder" is compared with MLS measurements. This seasonal anomaly was calculated by subtracting the long-term average over the entire time period (2005-2012) from the monthly climatology at each level. For an appropriate comparison, the CLaMS values were vertically convoluted with the averaging kernels of the MLS CO measurements. The simulation successfully reproduced the observed approximately 1-year tape recorder pattern of CO (Schoeberl et al., 2006; Liu et al., 2007, 2013). Further, the onset (at $\approx 100 \mathrm{hPa}$ ) of enhanced as well as of reduced $\mathrm{CO}$ volume mixing ratios are well described in the CLaMS simulation. This indicates that the seasonality of the tropospheric sources of $\mathrm{CO}$ and the convective upward transport of $\mathrm{CO}$ up to $\approx 100 \mathrm{hPa}$ are sufficiently well reproduced in the CLaMS simulations. However, compared to the MLS observations, the phase shift of the simulated tape recorder pattern with altitude, and thus the rate of tropical upwelling is too fast (Fig. 3). We attribute this model deficiency to an overestimate of the rate of tropical upwelling in the lower stratosphere in the ERA-Interim reanalyses, which has also been reported in previous studies (Dee et al., 2011; Schoeberl et al., 2012; Ploeger et al., 2012a). Moreover, there are some differences between the CLaMS simulated anomalies and the MLS measurements noticeable in Fig. 3, which cannot be attributed solely to problems in the rate of tropical upwelling.

In both the observations and the results of the simulations, the tape recorder anomaly pattern is only visible up to about $30 \mathrm{hPa}$ (Fig. 3). At these altitudes, the $\mathrm{CO}$ anomaly patterns are propagating downward rather than upward, as it is the case below $30 \mathrm{hPa}$. A downward propagation of tropical anomaly patterns is observed for long lived trace species, for which mixing ratios decline steadily with altitude in the stratosphere (Schoeberl et al., 2008; Kellmann et al., 2012; Khosrawi et al., 2013, see also Sect. 4.2). These anomaly patterns are attributed to a modulation of the vertical velocity in the tropical stratosphere induced by the QBO (Ribera et al., 2004; Punge et al., 2009; Flury et al., 2013), acting on the vertical gradient of long lived tracers (see Sect. 4.2).

However, tropical mixing ratios of $\mathrm{CO}$ decline with increasing altitude up to $\approx 40 \mathrm{hPa}$, but increase again at altitudes above $\approx 20 \mathrm{hPa}$ (see Supplement), so that the impact 

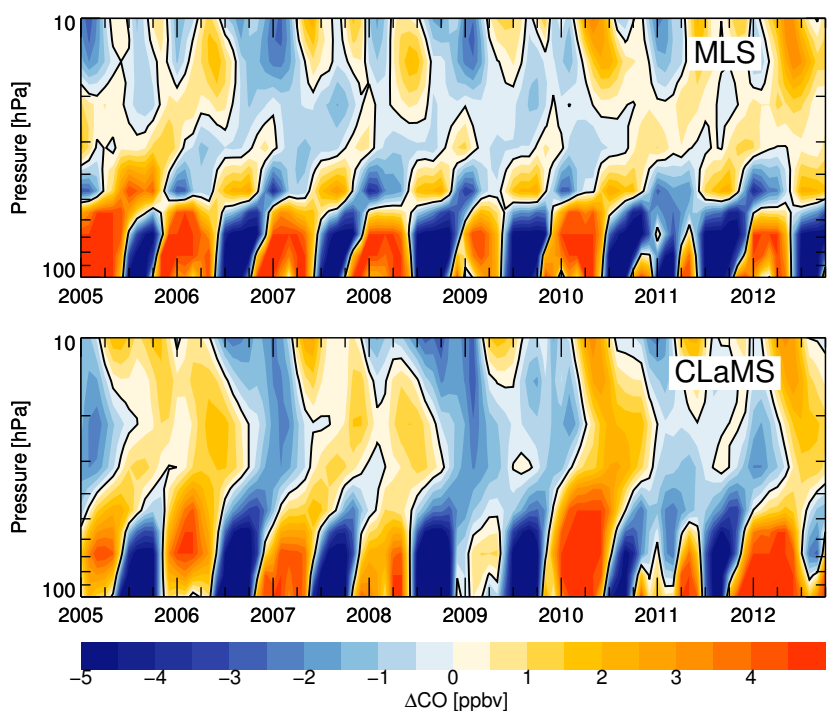

Figure 3. Comparison of $\mathrm{CO}$ anomalies, zonally averaged in the latitude band $\pm 15^{\circ}$ from MLS measurements (top panel) and the CLaMS simulation (bottom panel) for the time period 1 January 2005 to 31 October 2012. The CLaMS values were vertically smoothed employing the averaging kernels of the MLS measurements. The black lines in both panels indicate where the anomaly is zero.

of a QBO induced modulation of the vertical velocity in the tropics on $\mathrm{CO}$ anomaly patterns is complex. Nonetheless, the rate of downward propagation of $\mathrm{CO}$ anomaly patterns between 10 and $30 \mathrm{hPa}$ is consistent with the rate of downward propagation of the QBO (not shown). We therefore attribute the variation of the $\mathrm{CO}$ anomaly patterns between 10 and $30 \mathrm{hPa}$ (Fig. 3) as being influenced by the secondary meridional circulation in the tropical stratosphere induced by the QBO.

\subsection{Comparison of simulated $\mathrm{CO}$ with in situ measurements}

Because of their high spatial and temporal resolution, in situ measurements of $\mathrm{CO}$ in the upper troposphere and lower stratosphere from the COLD instrument allow the quality of the vertical structure of $\mathrm{CO}$ in the CLaMS simulations to be evaluated. In Fig. 4 we show the vertical profile of CO volume mixing ratio measured by COLD during four flights of the TROCCINOX campaign, which took place in February 2005 in Araçatuba $\left(21.2^{\circ} \mathrm{S}, 50.4^{\circ} \mathrm{W}\right)$, Brazil (Konopka et al., 2007). For the flights on 4, 5, 8, and 12 February 2005, $\mathrm{CO}$ measurements from the HAGAR instrument are available. The flights on 4 and 5 February 2005 were planned in order to sample air masses influenced by fresh convection in the vicinity of isolated thunderstorms ("storm chase"); the flight on 5 February 2005 also aimed at a plume re-encounter. The flights on 8, 12 and 15 February 2005 were designed as survey flights of the TTL in tropical air northward of the subtropical jet; the flight on 8 February also aimed at a stratospheric intrusion, the objective of the last two flights was, in particular, the validation of satellite measurements.

The comparison for all flights (Fig. 4) shows that in the CLaMS simulation, the low stratospheric mixing ratios of $\mathrm{CO}$ at altitudes greater than about $390 \mathrm{~K}$ are reproduced reasonably well, although a low bias in the model results is notable, in particular compared to the COLD CO measurements. In this altitude region, HAGAR and COLD CO measurements agree within error bars. However, the strong enhancement of $\mathrm{CO}$ at altitudes below, with observed peak values of CO of about $120-130 \mathrm{ppbv}$ at $350-360 \mathrm{~K}$ are substantially underestimated in the model simulation. In this altitude region, the HAGAR measurements generally support the conclusions based on the COLD measurements, but show lower peak $\mathrm{CO}$ values than COLD and thus a better agreement with the CLaMS simulations (see Appendix A for a brief discussion of the agreement between COLD and HAGAR measurements).

We attribute the observed strong $\mathrm{CO}$ enhancement at 350$360 \mathrm{~K}$ to air that is lofted by convection to these altitudes and thereafter injected into the upper troposphere in the convective outflow region. Indeed, young air masses, with a simulated mean age of air of less than a month, are found at $\approx 360 \mathrm{~K}$ in the model and the youngest air masses show the highest CO mixing ratios. Nonetheless, the simulated mean age of air is not compatible with fresh convection. Consequently, we interpret the observed model underestimate of $\mathrm{CO}$ as being caused by the lack of a representation of rapid convective uplift and of sufficiently high surface concentrations of $\mathrm{CO}$ in this model version of CLaMS. The simplified chemistry scheme employed here is unlikely to have an influence on the underestimated $\mathrm{CO}$ values, given the tropospheric lifetime of $\mathrm{CO}$ (about two months) and the very rapid (order of a day) timescales of convective transport. The model produces some signature of convectively driven upward transport as a peak in the $\mathrm{CO}$ distribution at about $360 \mathrm{~K}$ that coincides with young air masses, recently lofted from the ground; in particular for the flights on 5 and 15 February 2005. Thus, for these flights, the ERA-Interim vertical winds employed in the CLaMS simulation discussed here (a combination of $\omega=\dot{p}$ and $\dot{\theta}$, see Sect. 3.1), contain some signature of the convective activity that was sampled, albeit a much weaker one than in reality. However, the convectively enhanced CO observed on 4 and 12 February 2005, is not well reproduced in the CLaMS simulations.

The best reproduction by the CLaMS simulations of the measured $\mathrm{CO}$ mixing ratios is for the flights on 8 and 15 February (Fig. 4). Although the CLaMS values are somewhat lower than observed values, the agreement is generally reasonable with both the decline of $\mathrm{CO}$ with altitude above about $350 \mathrm{~K}$ and the enhancement in the upper troposphere being reproduced in the simulation. There is some indication of an underestimate of the peak $\mathrm{CO}$ in the convective outflow region for the flight on 15 February (at $\approx 340-350 \mathrm{~K}$ ), 


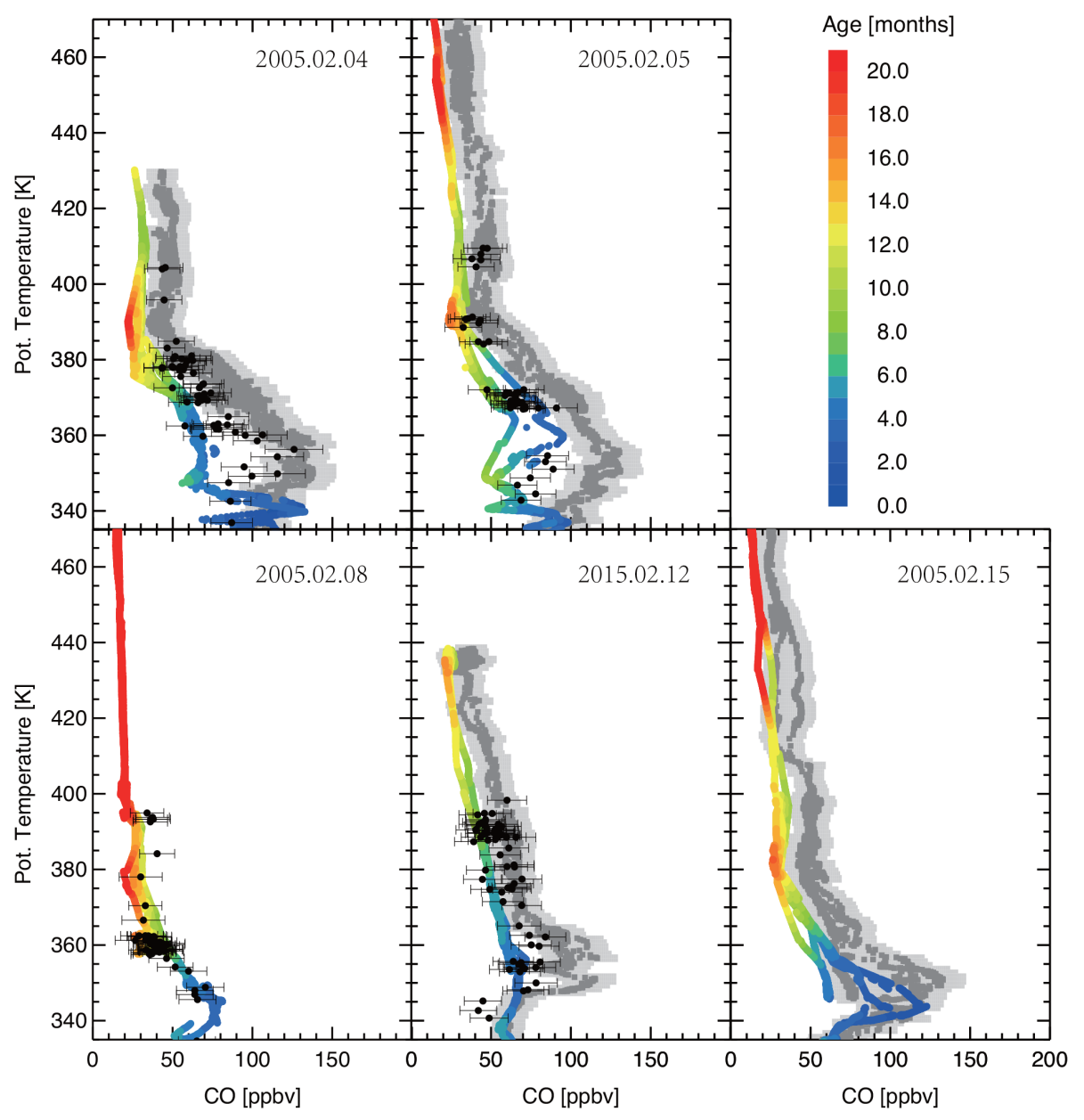

Figure 4. Comparison of the simulation of CO from CLaMS (coloured) with in situ measurements from the COLD instrument (dark grey) and the HAGAR instrument (black) on the Geophysica aircraft. The flights were conducted on 4 February 2005 (top left panel), 5 February 2005 (top right panel), 8 February 2005 (bottom left panel), 12 February 2005 (bottom middle panel), 15 February 2005 (bottom right panel). Note that HAGAR measurements are not available for 15 February 2005 and COLD measurements are not available for 8 February 2005. The mean age of air calculated by the model is colour-coded and given in months. The total measurement uncertainty is shown for both instruments (light grey shading for COLD and black error bars for HAGAR. (Total measurement uncertainty is determined as the square root of the sum of squares of the accuracy and precision of the measurements).

but much less pronounced than for the flights on 2, 5, and 12 February. For the TROCCINOX flights, a discrepancy between CLaMS results and in situ measurements are also observed at greater altitudes (Fig. 4). The underestimate of the CLaMS values above $\approx 400 \mathrm{~K}$ in the lower stratosphere is about 10-15 ppb. Although HAGAR and COLD measurements generally agree within the combined uncertainty estimates (see Appendix A for details), there is a tendency for HAGAR CO measurements to be lower than COLD values. In particular at altitudes between 380 to $340 \mathrm{~K}$, the HAGAR $\mathrm{CO}$ values agree somewhat better with the CLaMS simulations than COLD values.

The comparison of the CLaMS results with the COLD measurements during the SCOUT-O3 campaign in November 2005 (Brunner et al., 2009) and the AMMA campaign in July and August 2008 (Cairo et al., 2010) shows a much closer agreement. This is true in particular for SCOUT-O3, where an underestimate of the in situ measurements by the simulation is not noticeable. The climatological mean values of CLaMS simulations and COLD measurements agree rather well for both the AMMA and SCOUT-O3 measurements (Fig. 5). The lack of a good representation of rapid convective uplift in the CLaMS model is less problematic for the SCOUT-O3 and the AMMA measurements, because during these campaigns strong convectively driven $\mathrm{CO}$ enhancements at the bottom of the TTL were not sampled (see also Supplement).

In summary, we found from the analysis of the vertical CO profiles measured in situ: 

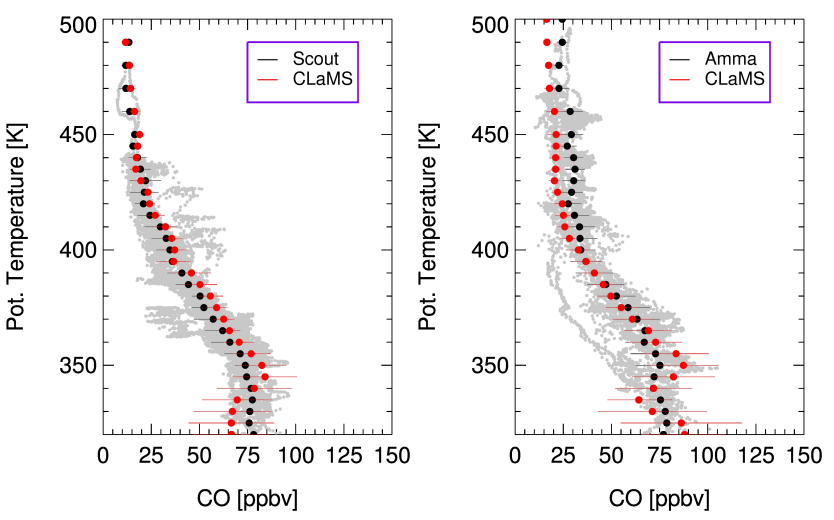

Figure 5. Climatological comparison of vertical CO profiles measured by the COLD instrument aboard the Geophysica aircraft in the tropical tropopause region with CLaMS simulations. The climatology of CO measurements (grey dots) is based on the COLD measurements in the campaigns SCOUT-O3 (November 2005, left panel, Brunner et al., 2009) and AMMA (Summer 2006, right panel, Cairo et al., 2010). The vertical profile of the mean of all CO measurements in the respective campaigns is shown as black symbols with the horizontal bars denoting the standard deviation of the mean. The corresponding model values (derived by interpolating the model information on the location and time of the measurements) are shown in red.

- Reasonable representation of lower CO values in the lower tropical stratosphere, with a tendency for underestimation (by $\approx 10-15 \mathrm{ppbv}$ ) during TROCCINOX;

- Insufficient representation of strongly enhanced CO in the convective outflow region during TROCCINOX; and

- Good representation of CO values in the lower tropical stratosphere during SCOUT-O3 and AMMA in the absence of convectively enhanced $\mathrm{CO}$.

In Fig. 6 the probability density functions (PDFs) are shown for scatter plots of a climatology of $\mathrm{CO}$ measured in several aircraft campaigns against the corresponding CLaMS simulations. The climatology of $\mathrm{CO}$ measurements is based on the COLD measurements aboard the Geophysica aircraft in the tropical tropopause region in the campaigns TROCCINOX (February 2005, Konopka et al., 2007), SCOUT-O3 (November 2005, Brunner et al., 2009) and AMMA (Summer 2006, Cairo et al., 2010) and on in situ CO measurements by the TRISTAR instrument in the mid-latitude tropopause region during the SPURT campaign (November 2001 to July 2003, Hoor et al., 2004; Engel et al., 2006). For the lowest mixing ratios of $\mathrm{CO}$, below about $50 \mathrm{ppbv}$, the maximum values of the PDFs cluster close to, but somewhat below, the $1: 1$ line, indicating that simulated $\mathrm{CO}$ values are slightly lower than observed values under these conditions. However, for simulated $\mathrm{CO}$ values between $\approx 50$ to $130 \mathrm{ppbv}$ there is also a clear tendency for the range of observed $\mathrm{CO}$ values

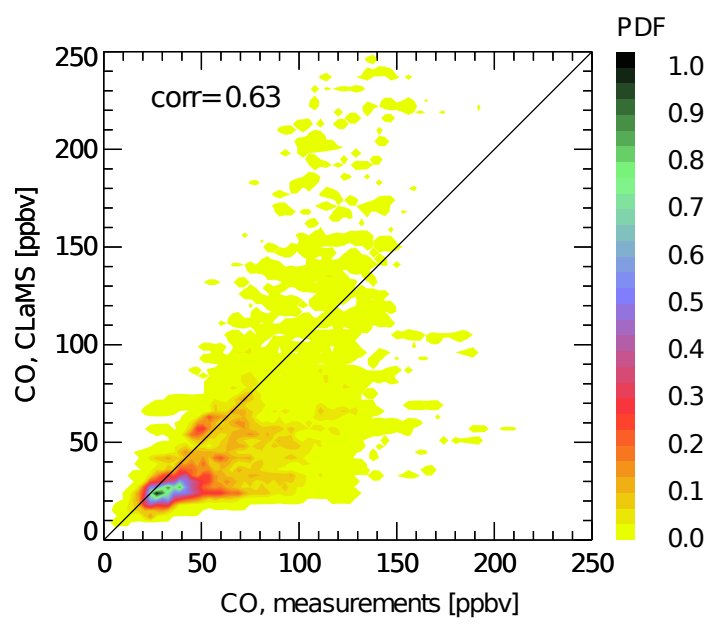

Figure 6. Probability density function for a scatter plot of a climatology of aircraft based CO measurements against CLaMS model simulations. The climatology of CO measurements is based on the COLD measurements aboard the Geophysica in the campaigns TROCCINOX (February 2005, Konopka et al., 2007), SCOUTO3 (November 2005, Brunner et al., 2009), and AMMA (Summer 2006, Cairo et al., 2010) as well as on the TRISTAR CO measurements in the mid-latitude tropopause region during the SPURT campaign from November 2001 to July 2003 (Hoor et al., 2004).

to extend to much higher values than simulated. For simulated $\mathrm{CO}$ mixing ratios above about $130 \mathrm{ppbv}$, i.e. for lower altitudes, the situation is different, with observed $\mathrm{CO}$ values being lower than simulated by CLaMS. It is not surprising that the model underestimates the variability of $\mathrm{CO}$ values in the tropical tropopause region, and in particular does not reproduce large $\mathrm{CO}$ values at the bottom of the TTL, because the upward transport in the troposphere is represented in the model solely by the large-scale vertical winds (i.e. a combination of $\omega=\dot{p}$ and $\dot{\theta}$, see Sect. 3.1), which do not contain sufficient information on convectively driven uplift and vertical mixing, in particular from sub-grid scale processes.

Thus, in summary, we conclude that the lack of a representation of convectively driven uplift of trace species in the troposphere in CLaMS does not substantially impact the simulation of $\mathrm{CO}$ for tropical background conditions. For a successful representation of the impact on $\mathrm{CO}$ of individual convective events, for example as observed for the flight on 5 February 2005 (Fig. 4), an appropriate representation of convective uplift and an accurate description of $\mathrm{CO}$ concentrations in the lowermost troposphere in the model are necessary.

\subsection{Simulated tropical anomalies of long-lived tracers}

The tape recorder signal in $\mathrm{CO}$, and similarly in $\mathrm{HCN}$, is attributed to seasonal or irregular variations in biomass burning emissions (Schoeberl et al., 2006; Pommrich et al., 2010). The situation is different for long-lived tracers (e.g. $\mathrm{N}_{2} \mathrm{O}$, 

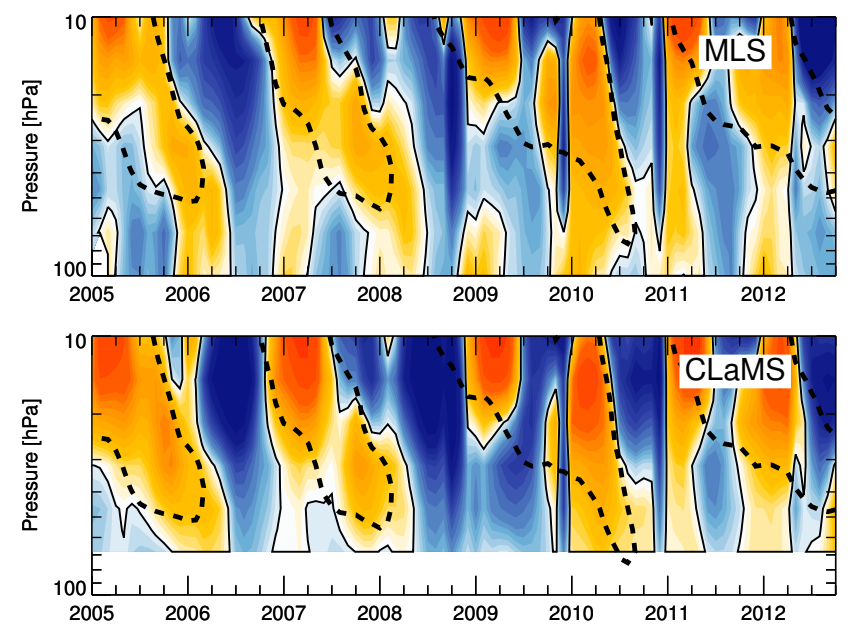

Figure 7. The anomaly pattern of tropical $\left( \pm 15^{\circ}\right) \mathrm{N}_{2} \mathrm{O}$ as observed by MLS (top panel) and as simulated by CLaMS (bottom panel) for the time period 1 January 2005 to 31 October 2012. In contrast to Fig. 8 below, the CLaMS results are interpolated here on the MLS measurement locations and convoluted with the averaging kernels of MLS for a more accurate comparison. Dashed contours $\left(-15 \mathrm{~m} \mathrm{~s}^{-1}\right.$ wind line from ERA-Interim) illustrate the easterly shear phase of the QBO.

$\mathrm{CH}_{4}, \mathrm{CCl}_{3} \mathrm{~F}, \mathrm{CCl}_{2} \mathrm{~F}_{2}$ ), which do not have sources strongly varying with season (or other irregular variations as observed for $\mathrm{HCN}$ ) and thus will have only small annual (or irregular) variation at the tropical tropopause.

Mixing ratios of long-lived tracers exhibit a vertical gradient in the tropical lower stratosphere. This vertical gradient is mostly due to in-mixing of photochemically aged midlatitude air (which exhibits reduced tracer values), with some contribution of local (tropical) photochemical loss (Volk et al., 1996). Variations of the vertical velocity in the tropical stratosphere, acting on this gradient, should result in anomaly patterns in long-lived tracers. In particular, the QBO is known to exert a significant modulation of tropical upwelling with the easterly shear phase of the QBO corresponding to enhanced upwelling and the westerly shear phase to reduced upwelling (Ribera et al., 2004; Punge et al., 2009; Flury et al., 2013).

In Fig. 7, the tropical $\left( \pm 15^{\circ}\right)$ anomaly patterns for $\mathrm{N}_{2} \mathrm{O}$, observed by MLS (top panel) and simulated by the CLaMS model (bottom panel) for the time period from January 2005 to the end of October 2012 are shown. The CLaMS model results were convoluted with the MLS averaging kernels to allow a more appropriate comparison. No CLaMS values are shown below $70 \mathrm{hPa}$ in Fig. 7, because at $100 \mathrm{hPa}$ the contribution of the a priori to the MLS measurements is relatively high (sum of the averaging kernels 0.7). As expected, there is no signature of a tape recorder signal for $\mathrm{N}_{2} \mathrm{O}$, but rather a distinctive anomaly pattern propagating downwards with time. The positive anomalies in $\mathrm{N}_{2} \mathrm{O}$ at $10-20 \mathrm{hPa}(\approx 700$ $800 \mathrm{~K}$ ) in 2005,2007 , and 2011 coincide with the easterly
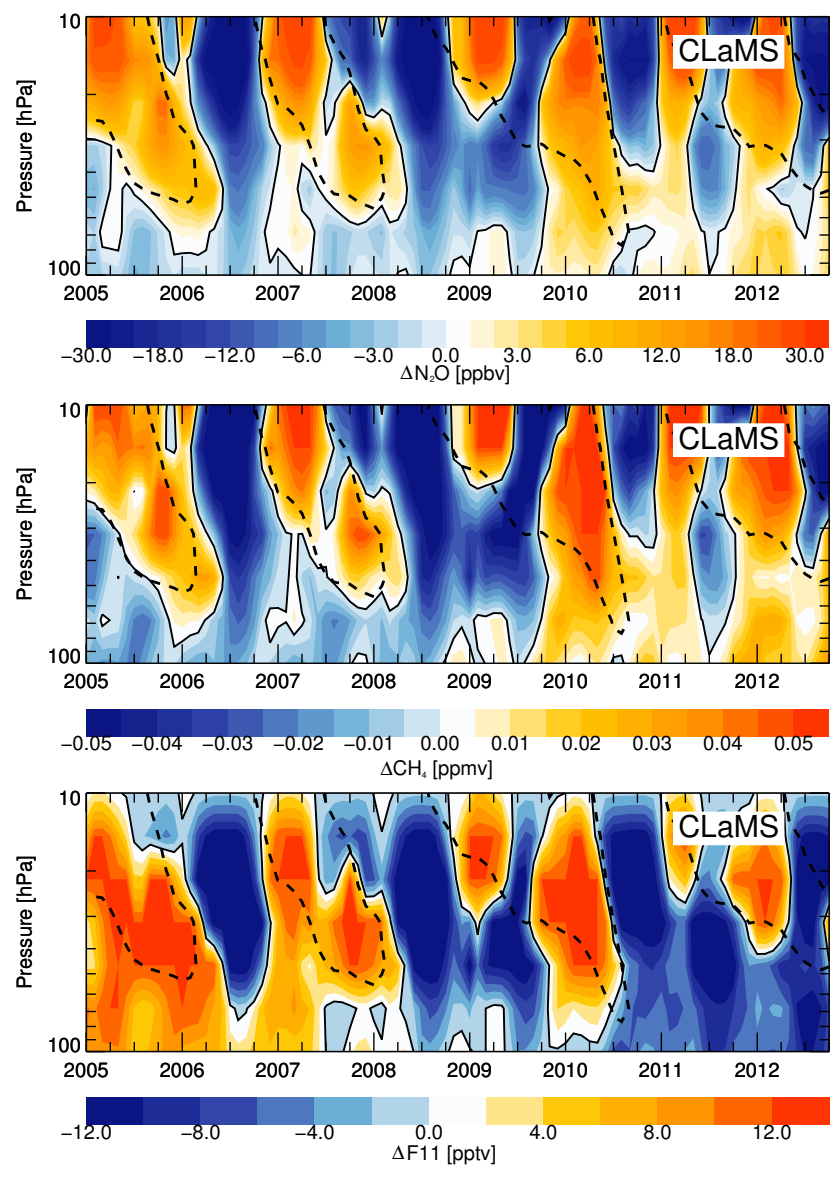

Figure 8. The anomaly pattern of tropical $\left( \pm 15^{\circ}\right)$ tracer fields as simulated by CLaMS for the time period 1 January 2005 to 31 October 2012. Top panel shows $\mathrm{N}_{2} \mathrm{O}$, middle panel $\mathrm{CH}_{4}$, and bottom panel $\mathrm{CCl}_{3} \mathrm{~F}$ (CFC-11). Dashed contours $\left(-15 \mathrm{~m} \mathrm{~s}^{-1}\right.$ wind line from ERA-Interim) illustrate the easterly phase of the QBO.

phase of the QBO at these times (see dashed black line in Fig. 7; QBO zonal pattern is deduced from ERA-Interim). Also the somewhat extended phase of easterlies at $10-20 \mathrm{hPa}$ between the end of 2008 and early 2010 is reflected in positive anomalies of $\mathrm{N}_{2} \mathrm{O}$ (albeit interrupted by negative anomalies at the end of 2009). Thus, in agreement with previous studies (e.g. Kellmann et al., 2012; Khosrawi et al., 2013), we interpret the positive anomalies in long-lived tracers as being caused by enhanced upwelling during the period when the QBO is in easterly shear phase. Very good agreement between $\mathrm{N}_{2} \mathrm{O}$ anomaly patterns simulated by CLaMS and MLS observation is obvious (Fig. 7); the onset of positive and negative anomalies of $\mathrm{N}_{2} \mathrm{O}$ at about $800 \mathrm{~K}$, and, in particular, its interannual variation are well reproduced by the simulations. Further, the observed velocity of the downward propagation of the anomaly is well captured by the simulations.

The tropical $\left( \pm 15^{\circ}\right)$ anomaly patterns simulated by the CLaMS model for $\mathrm{N}_{2} \mathrm{O}, \mathrm{CH}_{4}$, and $\mathrm{CCl}_{3} \mathrm{~F}$ are shown in Fig. 8; here the pure model results are shown without applying the 
MLS averaging kernels. Clearly, the anomaly pattern is robust and consistent for all three species. This finding corroborates the conclusion of the anomaly pattern being caused by the secondary meridional circulation induced by the QBO. The impact of convoluting the results of the CLaMS simulation with the MLS averaging kernels is limited (compare Fig. 7, bottom panel and Fig. 8, top panel).

The CLaMS simulation shows that an anomaly pattern as simulated for $\mathrm{N}_{2} \mathrm{O}$ and $\mathrm{CH}_{4}$ is also clearly pronounced in the simulation of $\mathrm{CCl}_{3} \mathrm{~F}$ (CFC-11) (Fig. 8, bottom panel). However, because the stratospheric loss rate for $\mathrm{CCl}_{3} \mathrm{~F}$ in the tropics is substantial at altitudes between about $\approx 55-10 \mathrm{hPa}$ (500-800 K, 20-30 km) (e.g. Minschwaner et al., 2013; Ko et al., 2013), the anomaly pattern for $\mathrm{CCl}_{3} \mathrm{~F}$ starts to weaken at about $10 \mathrm{hPa}(800 \mathrm{~K})$. There is also an obvious signal of a decline of $\mathrm{CCl}_{3} \mathrm{~F}$ at $100-70 \mathrm{hPa}(350-400 \mathrm{~K})$ over the considered time period between 2005 to 2012 (by about 18 pptv). This signal is caused by the decline in tropospheric concentrations due to the regulations of the Montreal protocol and its amendments and adjustments. It is consistent in magnitude with the observed decline of $\mathrm{CCl}_{3} \mathrm{~F}$ in the troposphere over this time period (WMO, 2011; Montzka, 2012) ${ }^{3}$ and with satellite measurements of $\mathrm{CCl}_{3} \mathrm{~F}$ between July 2002 and April 2011 (Kellmann et al., 2012).

\section{Conclusions}

We presented a simplified chemistry scheme for the chemical transport model CLaMS for the simulation of CO, ozone, and long-lived trace substances $\left(\mathrm{CH}_{4}, \mathrm{~N}_{2} \mathrm{O}, \mathrm{CCl}_{3} \mathrm{~F}\right.$ (CFC11), $\mathrm{CCl}_{2} \mathrm{~F}_{2}$ (CFC-12), and $\mathrm{CO}_{2}$ ) in the lower tropical stratosphere at comparatively low numerical cost. The boundary condition at the ground is represented for the long-lived trace substances $\mathrm{CH}_{4}, \mathrm{~N}_{2} \mathrm{O}, \mathrm{CCl}_{3} \mathrm{~F}, \mathrm{CCl}_{2} \mathrm{~F}_{2}$, and $\mathrm{CO}_{2}$ based on ground-based measurements. The boundary conditions for $\mathrm{CO}$ in the troposphere are based on MOPITT V4 measurements (at $\approx 700-200 \mathrm{hPa}$ ). Here we have focused on the quality of the simulated $\mathrm{CO}$ and long-lived tracer fields in the TTL and in the lower tropical stratosphere (see Ploeger et al., 2011, 2012b, for a discussion of the simulated ozone budget in the TTL).

The model simulations do not very well reproduce strongly enhanced $\mathrm{CO}$ due to pollution events and especially enhanced $\mathrm{CO}$ observed in the convective outflow region. We attribute this deficiency to the lack of a good representation of tropospheric mixing and of convectively driven uplift in this model version, together with the limitations of the $\mathrm{CO}$ boundary condition in the lower troposphere (see Sect. 3.3). Nonetheless, in the TTL and the lower tropical stratosphere, there is relatively good agreement of simulated $\mathrm{CO}$ with in situ measurements, with the exception of the TROCCINOX campaign, where $\mathrm{CO}$ in the simulation is biased low (by $\approx 10-15 \mathrm{ppbv}$ ).

\footnotetext{
${ }^{3}$ See also http://www.esrl.noaa.gov/gmd/hats/insitu/cats/.
}

However, the model simulations allow the large scale anomaly patterns of $\mathrm{CO}$ in the lower stratosphere to be reproduced. In particular, the simulated zonally averaged tropical $\mathrm{CO}$ anomaly patterns (the so called "tape recorder" patterns) are in good agreement with observations. The reproduction of the tape recorder patterns in the simulations implies that the seasonality of the tropospheric sources of $\mathrm{CO}$ and the convective upward transport of CO to the bottom of the TTL are sufficiently well reproduced in the CLaMS model version presented here. This further indicates that on large temporal and spatial scales, the information contained in the ERAInterim winds is sufficient to describe upward transport in the tropical troposphere to the bottom of the TTL. The simulations show a too rapid upwelling compared to observations, which is due to the known overestimated vertical velocities in the tropical lower stratosphere and in the TTL in the ERA-Interim reanalysis data set (Dee et al., 2011; Schoeberl et al., 2012; Ploeger et al., 2012a). Finally, the simulated tropical anomaly patterns of $\mathrm{N}_{2} \mathrm{O}$ are in good agreement with observations. In the simulations, anomaly patterns of $\mathrm{CH}_{4}$ and $\mathrm{CFC}-11$ were found to be very similar to those of $\mathrm{N}_{2} \mathrm{O}$. Further, for all long-lived tracers, the occurrence of positive anomalies is consistent with enhanced tropical upwelling caused by the easterly shear phase of the QBO (Ribera et al., 2004; Punge et al., 2009; Flury et al., 2013).

In summary, we found that this model version of CLaMS has certain deficiencies in describing enhanced pollution events especially in the convective outflow region, but is of sufficient quality to allow background conditions in the TTL and lower tropical stratosphere to be described. In particular, the zonally averaged tropical $\mathrm{CO}$ anomaly patterns (i.e. the CO tape recorder signal) and the tropical anomalies of $\mathrm{N}_{2} \mathrm{O}$ simulated by this model version of CLaMS are in good agreement with observations.

Future work with the model will focus on an improved representation of rapid convective upward transport and of tropospheric mixing, on an improved representation of trace gas sources in the lower troposphere and on employing different and improved meteorological reanalysis schemes.

\section{Code availability}

The code for the various components of the Chemical Lagrangian Model of the Stratosphere (CLaMS), including the developments presented here can be obtained from the CLaMS team via the corresponding author of this paper. The main tool for an independent implementation of the simplified stratospheric chemistry described here (Sect. 3.2) beyond the list of reactions, are the pre-calculated tables of the radical species. These tables are available as a Supplement to this paper. 
Appendix A: Comparison CO measurements by COLD with measurements by HAGAR on the Geophysica and with VUV fluorescence measurements on the Falcon

In situ measurements of $\mathrm{CO}$ during the TROCCINOX campaign are used for the evaluation of the CLaMS simulation results. In this Appendix, we compare all three available CO measurements during TROCCINOX, namely the COLD (Viciani et al., 2008) and HAGAR (Volk et al., 2000; Homan et al., 2010) measurements on the Geophysica and the VUV fluorescence measurements on the Falcon (Gerbig et al., 1999; Roiger et al., 2011); this allows the accuracy of the measurements to be assessed.

Figure A1 shows a comparison of the measured $\mathrm{CO}$ time series by the HAGAR and COLD instruments during the flights on 4, 5, and 12 February 2005 in the frame of TROCCINOX. Within the reported uncertainty range of the two measurements, on all three days, there is agreement for $\mathrm{CO}$ volume mixing ratios below about 50 ppbv. There is further agreement within the combined error bars for the measurements on 4 February 2005 and 12 February 2005. Solely for the flight on 5 February 2005, for mixing ratios greater than about $50 \mathrm{ppbv}$, there is less agreement between the two measurements, with HAGAR showing lower values than COLD.
Furthermore, the CO measurements of the COLD instrument onboard the Geophysica on 4, 5, 15, and 18 February 2005 may be compared with the $\mathrm{CO}$ measurements on the research aircraft Falcon. The CO measurements aboard the Falcon were conducted with a vacuum-UV fluorescence instrument (Gerbig et al., 1999; Roiger et al., 2011) with an accuracy of $3 \mathrm{ppbv}$, a precision of $1 \mathrm{ppbv}$ and an averaging time of $5 \mathrm{~s}$. We compare the vertical profiles taken by the two instruments on ascent (Fig. A2) and descent (Fig. A3). The measurements were taken at approximately the same time; the time difference ranges between a few minutes and $2.5 \mathrm{~h}$ (see Table A1 for the exact time period).

In spite of the time delay between the two measurements, the agreement is good in general. The Falcon measurements tend to show somewhat lower $\mathrm{CO}$ mixing ratios than the COLD instrument and in cases with a delay in the measurements of about an hour (e.g. ascent on 4 February 2005, Fig. A2), features in the two vertical profile can be different. However, the values of the two CO measurements lie mostly within the combined error estimates over the altitude range $\approx 320-350 \mathrm{~K}$ and in the case of a close coincidence between the two measurements (ascent on 18 February 2005, Fig. A2), the agreement is very good above about $325 \mathrm{~K}$.
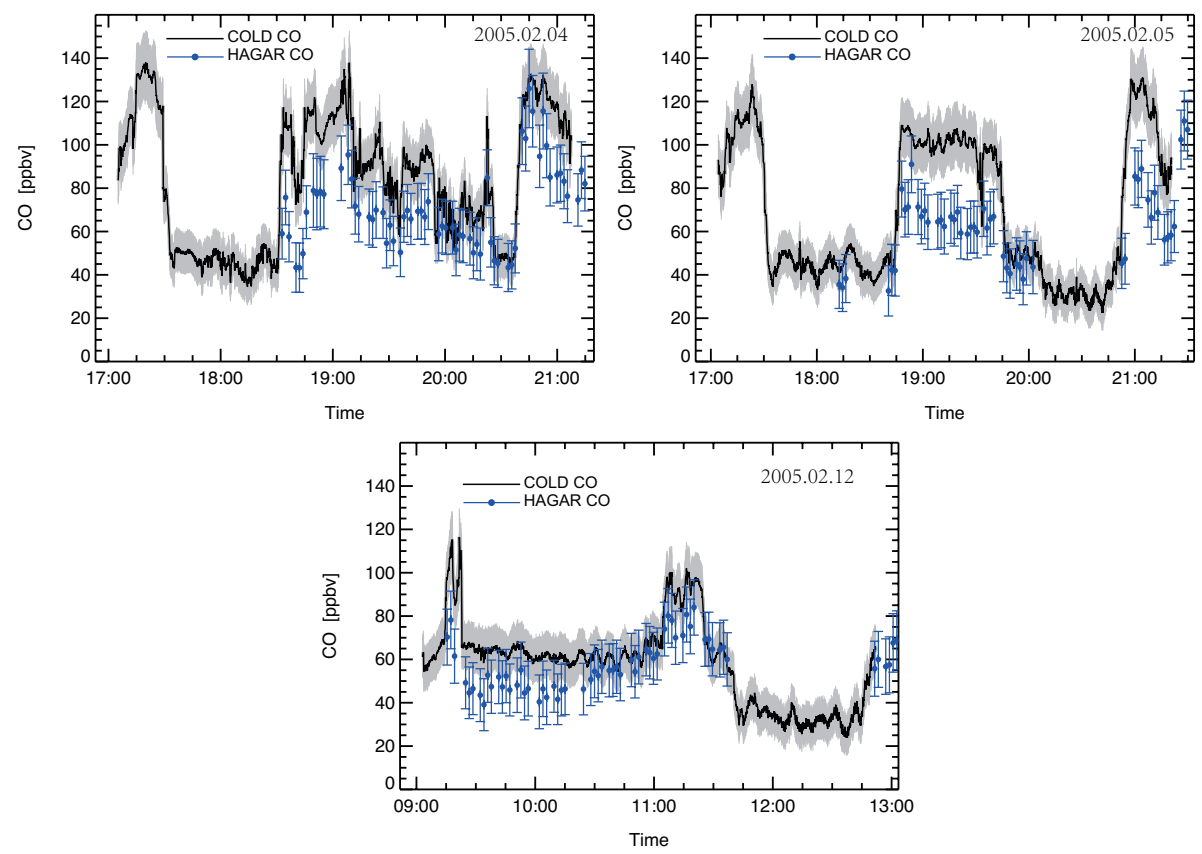

Figure A1. Comparison of HAGAR (blue symbols) and COLD CO measurements (black solid line) during three Geophysica flights in February 2005. The total measurement uncertainty for the COLD measurements is shown as a grey shading. The error bars for the HAGAR measurements also show total measurement uncertainty. Top left panel shows flight on 4 February 2005, top right panel the flight on 5 February, and bottom panel flight on 12 February 2005. 

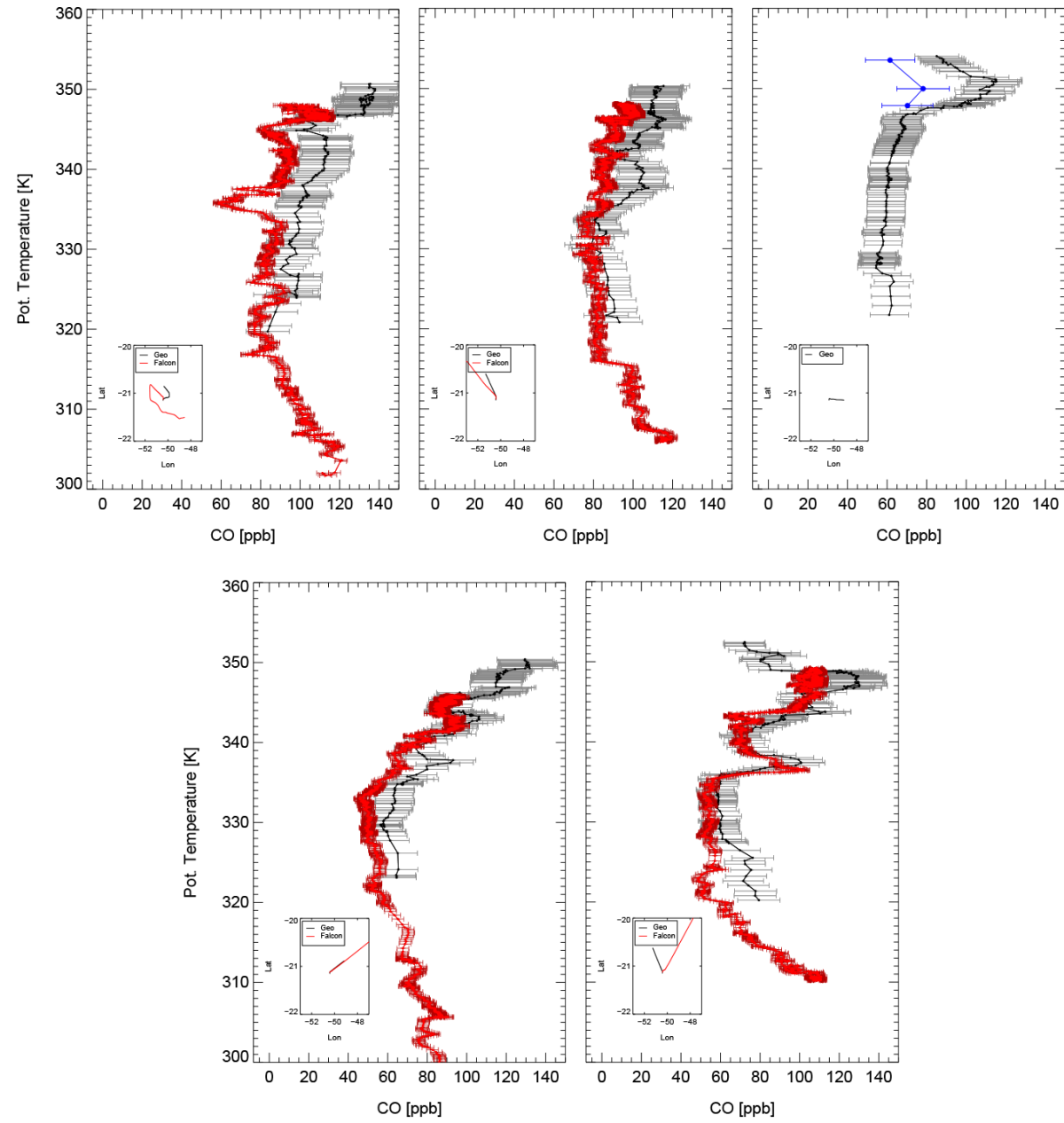

Figure A2. Comparison of CO measurements during ascent by the COLD instrument aboard the Geophysica (black) and CO measurements aboard the Falcon (red) (see Table A1 for the exact time period, which is compared). If available, data from HAGAR aboard the Geophysica are shown in blue. Shown are data for 4 February 2005 (top left), 5 February 2005 (top middle), 12 February 2005 (top right), 15 February 2005 (bottom left), and 18 February 2005 (bottom right). Total measurement uncertainty (determined as the square root of the sum of squares of the accuracy and precision of the measurements) is shown as uncertainty range for COLD and HAGAR.

Table A1. Time of ascent and descent measurements for the Geophysica and Falcon research aircraft during the TROCCINOX campaign (given in local time).

\begin{tabular}{llllll}
\hline & \multicolumn{2}{c}{ Ascent } & & \multicolumn{2}{c}{ Descent } \\
\cline { 2 - 3 } \cline { 5 - 6 } Flight & Geophysica & Falcon & & Geophysica & Falcon \\
\hline 4 Feb 2005 & $16: 39-18: 00$ & $17: 46-18: 30$ & & $20: 30-21: 24$ & $19: 45-20: 11$ \\
5 Feb 2005 & $16: 46-17: 39$ & $17: 56-18: 30$ & & $20: 40-21: 36$ & $20: 15-20: 42$ \\
8 Feb 2005 & $12: 47-13: 29$ & $12: 43-13: 15$ & & $16: 30-17: 33$ & $15: 23-15: 54$ \\
12 Feb 2005 & $08: 37-09: 38$ & - & & $13: 10-13: 45$ & - \\
15 Feb 2005 & $10: 07-11: 19$ & $10: 33-11: 30$ & & $13: 45-15: 09$ & $13: 00-14: 03$ \\
18 Feb 2005 & $17: 45-18: 15$ & $17: 45-18: 15$ & & $21: 03-21: 49$ & $18: 45-19: 11$ \\
\hline
\end{tabular}



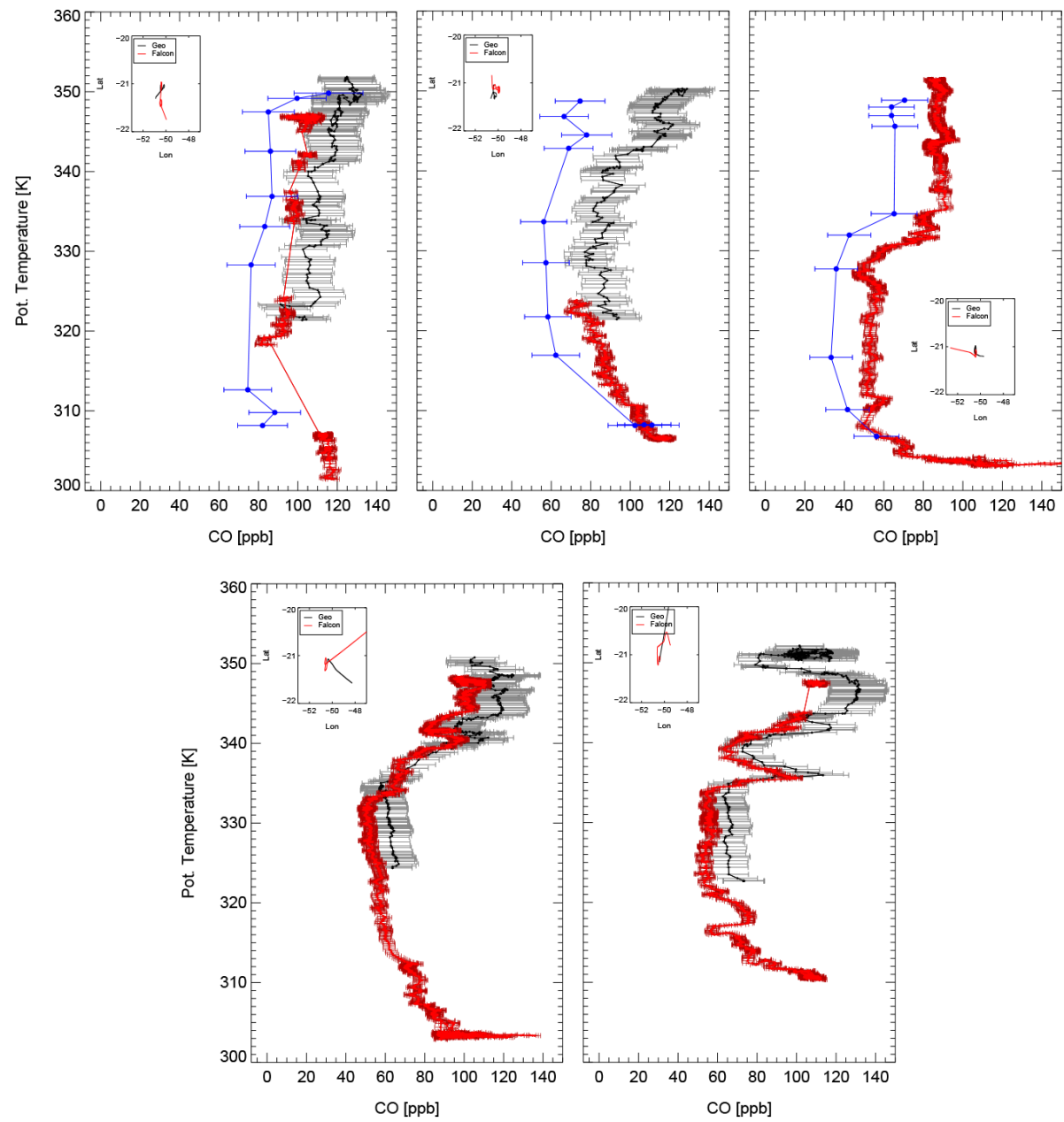

Figure A3. Comparison of CO measurements during descent by the COLD instrument aboard the Geophysica (black) and CO measurements aboard the Falcon (red) (see Table A1 for the exact time period, which is compared). If available, data from HAGAR aboard the Geophysica are shown in blue. Shown are data for 4 February 2005 (top left), 5 February 2005 (top middle), 8 February 2005 (top right), 15 February 2005 (bottom left) 18 February 2005 (bottom right). Total measurement uncertainty (determined as the square root of the sum of squares of the accuracy and precision of the measurements) is shown as uncertainty range for COLD and HAGAR. 


\section{The Supplement related to this article is available online at doi:10.5194/gmd-7-2895-2014-supplement.}

Acknowledgements. The authors thank Nicole Thomas for excellent programming support, which constituted an essential contribution to the work reported here. We also thank Felix Schaps for technical support in implementing the use of AIRS data as a lower boundary condition in the model. We are grateful to both the MOPITT and the MLS team for making such great research products publicly available. We thank the European Centre for Medium-Range Weather Forecasts (ECMWF) for providing meteorological analyses and the ERA-Interim reanalysis data. We further thank the experimental teams active in the M55-Geophysica campaigns TROCCINOX, SCOUT-O3, and AMMA and the teams of the research aircraft Falcon (TROCCINOX) and Lear-Jet (SPURT) for conducting the measurements, which were used in this work. The TROCCINOX campaign (including the M55-Geophysica research flights) was partially funded by the Commission of the European Community under the contract EVK2-CT-2001-00122 and by other TROCCINOX partners; the M55-Geophysica and Falcon flights in the frame of the SCOUT-O3 campaign in Darwin in early 2005 have been supported by an European Community grant through the project SCOUT-O3 under contract COCE-CT2004-505390; the M55-Geophysica campaign within the frame of AMMA was supported by the EEIG-Geophysica Consortium, CNRS-INSU, EC Integrated Projects AMMA-EU (contract number 004089-2), SCOUT-O3 and CNES. Part of the present work is also supported by the European Commission under the grant number StratoClim-603557-FP7-ENV.2013.6.1-2.

The service charges for this open access publication

have been covered by a Research Centre of the

Helmholtz Association.

Edited by: K. Gierens

\section{References}

Abalos, M., Randel, W. J., and Serrano, E.: Variability in upwelling across the tropical tropopause and correlations with tracers in the lower stratosphere, Atmos. Chem. Phys., 12, 11505-11517, doi:10.5194/acp-12-11505-2012, 2012.

Aumann, H. H., Chahine, M. T., Gautier, C., Goldberg, M., Kalnay, E., McMillin, L., Revercomb, H., Rosenkranz, P. W., Smith, W. L., Staelin, D., Strow, L., and Susskind, J.: AIRS/AMSU/HSB on the Aqua Mission: design, science objectives, data products and processing systems, IEEE T. Geosci. Remote, 41, 253-264, 2003.

Baldwin, M., Gray, L., Dunkerton, T., Hamilton, K., Haynes, P., Randel, W., Holton, J., Alexander, M., Hirota, I., Horinouchi, T., Jones, D., Kinnersley, J., Marquardt, C., Sato, K., and Takahashi, M.: The quasi-biennial oscillation, Rev. Geophys., 39, 179-229, 2001

Becker, G., Grooß, J.-U., McKenna, D. S., and Müller, R.: Stratospheric photolysis frequencies: impact of an improved numerical solution of the radiative transfer equation, J. Atmos. Chem., 37, 217-229, doi:10.1023/A:1006468926530, 2000.

Boynard, A., Pfister, G. G., and Edwards, D. P.: Boundary layer versus free tropospheric $\mathrm{CO}$ budget and variability over the United States during summertime, J. Geophys. Res., 117, D04306, doi:10.1029/2011JD016416, 2012.

Brown, A. T., Volk, C. M., Schoeberl, M. R., Boone, C. D., and Bernath, P. F.: Stratospheric lifetimes of CFC-12, $\mathrm{CCl}_{4}, \mathrm{CH}_{4}$, $\mathrm{CH}_{3} \mathrm{Cl}$ and $\mathrm{N}_{2} \mathrm{O}$ from measurements made by the Atmospheric Chemistry Experiment-Fourier Transform Spectrometer (ACEFTS), Atmos. Chem. Phys., 13, 6921-6950, doi:10.5194/acp-136921-2013, 2013.

Brunner, D., Siegmund, P., May, P. T., Chappel, L., Schiller, C., Müller, R., Peter, T., Fueglistaler, S., MacKenzie, A. R., Fix, A., Schlager, H., Allen, G., Fjaeraa, A. M., Streibel, M., and Harris, N. R. P.: The SCOUT-O3 Darwin Aircraft Campaign: rationale and meteorology, Atmos. Chem. Phys., 9, 93-117, doi:10.5194/acp-9-93-2009, 2009.

Cairo, F., Pommereau, J. P., Law, K. S., Schlager, H., Garnier, A., Fierli, F., Ern, M., Streibel, M., Arabas, S., Borrmann, S., Berthelier, J. J., Blom, C., Christensen, T., D’Amato, F., Di Donfrancesco, G., Deshler, T., Diedhiou, A., Durry, G., Engelsen, O., Goutail, F., Harris, N. R. P., Kerstel, E. R. T., Khaykin, S., Konopka, P., Kylling, A., Larsen, N., Lebel, T., Liu, X., MacKenzie, A. R., Nielsen, J., Oulanowski, A., Parker, D. J., Pelon, J., Polcher, J., Pyle, J. A., Ravegnani, F., Rivière, E. D., Robinson, A. D., Röckmann, T., Schiller, C., Simões, F., Stefanutti, L., Stroh, F., Some, L., Siegmund, P., Sitnikov, N., Vernier, J. P., Volk, C. M., Voigt, C., von Hobe, M., Viciani, S., and Yushkov, V.: An introduction to the SCOUT-AMMA stratospheric aircraft, balloons and sondes campaign in West Africa, August 2006: rationale and roadmap, Atmos. Chem. Phys., 10, 2237-2256, doi:10.5194/acp-10-2237-2010, 2010.

Dee, D. P., Uppala, S. M., Simmons, A. J., Berrisford, P., Poli, P., Kobayashi, S., Andrae, U., Balmaseda, M. A., Balsamo, G., Bauer, P., Bechtold, P., Beljaars, A. C. M., van de Berg, L., Bidlot, J., Bormann, N., Delsol, C., Dragani, R., Fuentes, M., Geer, A. J., Haimberger, L., Healy, S. B., Hersbach, H., Holm, E. V., Isaksen, L., Kallberg, P., Koehler, M., Matricardi, M., McNally, A. P., Monge-Sanz, B. M., Morcrette, J. J., Park, B. K., Peubey, C., de Rosnay, P., Tavolato, C., Thepaut, J. N., and Vitart, F.: The ERA-Interim reanalysis: configuration and performance of the data assimilation system, Q. J. Roy. Meteorol. Soc., 137, 553-597, doi:10.1002/qj.828, 2011.

Deeter, M. N., Emmons, L. K., Francis, G. L., Edwards, D. P., Gille, J. C., Warner, J. X., Khattatov, B., Ziskin, D., Lamarque, J.-F., Ho, S.-P., Yudin, V., Attié, J.-L., Packman, D., Chen, J., Mao, D., and Drummond, J. R.: Operational carbon monoxide retrieval algorithm and selected results for the MOPITT instrument, J. Geophys. Res., 108, 4399, doi:10.1029/2002JD003186, 2003.

Deeter, M. N., Emmons, L. K., Edwards, D. P., and Gille, J. C.: Vertical resolution and information content of $\mathrm{CO}$ profiles retrieved by MOPITT, Geophys. Res. Lett., 31, L15112, doi:10.1029/2004GL020235, 2004.

Deeter, M. N., Edwards, D. P., Gille, J. C., Emmons, L. K., Francis, G., Ho, S.-P., Mao, D., Masters, D., Worden, H., Drummond, J. R., and Novelli, P. C.: The MOPITT version 4 CO product: Algorithm enhancements, validation, and long-term stabil- 
ity, J. Geophys. Res., 115, D07306, doi:10.1029/2009JD013005, 2010.

Deeter, M. N., Worden, H. M., Gille, J. C., Edwards, D. P., Mao, D., and Drummond, J. R.: MOPITT multispectral CO retrievals: origins and effects of geophysical radiance errors, J. Geophys. Res., 116, D15303, doi:10.1029/2011JD015703, 2011.

Diallo, M., Legras, B., and Chédin, A.: Age of stratospheric air in the ERA-Interim, Atmos. Chem. Phys., 12, 12133-12154, doi:10.5194/acp-12-12133-2012, 2012.

Emmons, L. K., Deeter, M. N., Gille, J. C., Edwards, D. P., Attié, J.-L., Warner, J., Ziskin, D., Francis, G., Khattatov, B., Yudin, V., Lamarque, L.-F., Ho, S.-P., Mao, D., Chen, J. S., Drummond, J., Novelli, P., Sachse, G., Coffey, M. T., Hannigan, J. W., Gerbig, C., Kawakami, S., Kondo, Y., Takegawa, N., Schlager, H., Baehr, J., and Ziereis, H.: Validation of Measurements of Pollution in the Troposphere (MOPITT) CO retrievals with aircraft in situ profiles, J. Geophys. Res., 109, D03309, doi:10.1029/2003JD004101, 2004.

Emmons, L. K., Pfister, G. G., Edwards, D. P., Gille, J. C., Sachse, G., Blake, D., Wofsy, S., Gerbig, C., Matross, D., and Nédélec, P.: Measurements of Pollution in the Troposphere (MOPITT) validation exercises during summer 2004 field campaigns over North America, J. Geophys. Res., 112, D12S02, doi:10.1029/2006JD007833, 2007.

Emmons, L. K., Edwards, D. P., Deeter, M. N., Gille, J. C., Campos, T., Nédélec, P., Novelli, P., and Sachse, G.: Measurements of Pollution In The Troposphere (MOPITT) validation through 2006, Atmos. Chem. Phys., 9, 1795-1803, doi:10.5194/acp-91795-2009, 2009.

Engel, A., Bönisch, H., Brunner, D., Fischer, H., Franke, H., Günther, G., Gurk, C., Hegglin, M., Hoor, P., Königstedt, R., Krebsbach, M., Maser, R., Parchatka, U., Peter, T., Schell, D., Schiller, C., Schmidt, U., Spelten, N., Szabo, T., Weers, U., Wernli, H., Wetter, T., and Wirth, V.: Highly resolved observations of trace gases in the lowermost stratosphere and upper troposphere from the Spurt project: an overview, Atmos. Chem. Phys., 6, 283-301, doi:10.5194/acp-6-283-2006, 2006.

Flury, T., Wu, D. L., and Read, W. G.: Variability in the speed of the Brewer-Dobson circulation as observed by Aura/MLS, Atmos. Chem. Phys., 13, 4563-4575, doi:10.5194/acp-13-45632013, 2013.

Fueglistaler, S., Dessler, A. E., Dunkerton, T. J., Folkins, I., Fu, Q., and Mote, P. W.: Tropical tropopause layer, Rev. Geophys., 47, RG1004, doi:10.1029/2008RG000267, 2009.

Gerbig, C., Schmitgen, S., Kley, D., Volz-Thomas, A., Dewey, K., and Haaks, D.: An improved fast-response vacuum-UV resonance fluorescence CO instrument, J. Geophys. Res., 104, 16991704, 1999.

Grooß, J.-U.: Modelling of Stratospheric Chemistry based on HALOE/UARS Satellite Data, Ph.D. thesis, University of Mainz, 1996.

Grooß, J.-U., and Müller, R.: Simulation of ozone loss in Arctic winter 2004/2005, Geophys. Res. Lett., 34, L05804, doi:10.1029/2006GL028901, 2007.

Grooß, J.-U. and Russell III, James M.: Technical note: A stratospheric climatology for $\mathrm{O}_{3}, \mathrm{H}_{2} \mathrm{O}, \mathrm{CH}_{4}, \mathrm{NO}_{\mathrm{x}}, \mathrm{HCl}$ and $\mathrm{HF}$ derived from HALOE measurements, Atmos. Chem. Phys., 5, 2797-2807, doi:10.5194/acp-5-2797-2005, 2005.
Grooß, J.-U., Günther, G., Konopka, P., Müller, R., McKenna, D. S., Stroh, F., Vogel, B., Engel, A., Müller, M., Hoppel, K., Bevilacqua, R., Richard, E., Webster, C. R., Elkins, J. W., Hurst, D. F., Romashkin, P. A., and Baumgardner, D. G.: Simulation of ozone depletion in spring 2000 with the Chemical Lagrangian Model of the Stratosphere (CLaMS), J. Geophys. Res., 107, 8295, doi:10.1029/2001JD000456, 2002.

Grooß, J.-U., Günther, G., Müller, R., Konopka, P., Bausch, S., Schlager, H., Voigt, C., Volk, C. M., and Toon, G. C.: Simulation of denitrification and ozone loss for the Arctic winter 2002/2003, Atmos. Chem. Phys., 5, 1437-1448, doi:10.5194/acp-5-14372005, 2005.

Grooß, J.-U., Brautzsch, K., Pommrich, R., Solomon, S., and Müller, R.: Stratospheric ozone chemistry in the Antarctic: what determines the lowest ozone values reached and their recovery?, Atmos. Chem. Phys., 11, 12217-12226, doi:10.5194/acp11-12217-2011, 2011.

Grooß, J.-U., Engel, I., Borrmann, S., Frey, W., Günther, G., Hoyle, C. R., Kivi, R., Luo, B. P., Molleker, S., Peter, T., Pitts, M. C., Schlager, H., Stiller, G., Vömel, H., Walker, K. A., and Müller, R.: Nitric acid trihydrate nucleation and denitrification in the Arctic stratosphere, Atmos. Chem. Phys., 14, 1055-1073, doi:10.5194/acp-14-1055-2014, 2014.

Hoffmann, L., Hoppe, C. M., Müller, R., Dutton, G. S., Gille, J. C., Griessbach, S., Jones, A., Meyer, C. I., Spang, R., Volk, C. M., and Walker, K. A.: Stratospheric lifetime ratio of CFC-11 and CFC-12 from satellite and model climatologies, Atmos. Chem. Phys., 14, 12479-12497, doi:10.5194/acp-14-12479-2014, 2014.

Homan, C. D., Volk, C. M., Kuhn, A. C., Werner, A., Baehr, J., Viciani, S., Ulanovski, A., and Ravegnani, F.: Tracer measurements in the tropical tropopause layer during the AMMA/SCOUTO3 aircraft campaign, Atmos. Chem. Phys., 10, 3615-3627, doi:10.5194/acp-10-3615-2010, 2010.

Hoor, P., Gurk, C., Brunner, D., Hegglin, M. I., Wernli, H., and Fischer, H.: Seasonality and extent of extratropical TST derived from in-situ CO measurements during SPURT, Atmos. Chem. Phys., 4, 1427-1442, doi:10.5194/acp-4-1427-2004, 2004.

Hoppe, C. M., Hoffmann, L., Konopka, P., Grooß, J.-U., Ploeger, F., Günther, G., Jöckel, P., and Müller, R.: The implementation of the CLaMS Lagrangian transport core into the chemistry climate model EMAC 2.40.1: application on age of air and transport of long-lived trace species, Geosci. Model Dev., 7, 2639-2651, doi:10.5194/gmd-7-2639-2014, 2014.

Jöckel, P., Tost, H., Pozzer, A., Brühl, C., Buchholz, J., Ganzeveld, L., Hoor, P., Kerkweg, A., Lawrence, M. G., Sander, R., Steil, B., Stiller, G., Tanarhte, M., Taraborrelli, D., van Aardenne, J., and Lelieveld, J.: The atmospheric chemistry general circulation model ECHAM5/MESSy1: consistent simulation of ozone from the surface to the mesosphere, Atmos. Chem. Phys., 6, 5067-5104, doi:10.5194/acp-6-5067-2006, 2006.

Kellmann, S., von Clarmann, T., Stiller, G. P., Eckert, E., Glatthor, N., Höpfner, M., Kiefer, M., Orphal, J., Funke, B., Grabowski, U., Linden, A., Dutton, G. S., and Elkins, J. W.: Global CFC-11 $\left(\mathrm{CCl}_{3} \mathrm{~F}\right)$ and CFC-12 $\left(\mathrm{CCl}_{2} \mathrm{~F}_{2}\right)$ measurements with the Michelson Interferometer for Passive Atmospheric Sounding (MIPAS): retrieval, climatologies and trends, Atmos. Chem. Phys., 12, 11857-11875, doi:10.5194/acp-12-118572012, 2012. 
Khosrawi, F., Müller, R., Urban, J., Proffitt, M. H., Stiller, G., Kiefer, M., Lossow, S., Kinnison, D., Olschewski, F., Riese, M., and Murtagh, D.: Assessment of the interannual variability and influence of the QBO and upwelling on tracer-tracer distributions of $\mathrm{N}_{2} \mathrm{O}$ and $\mathrm{O}_{3}$ in the tropical lower stratosphere, Atmos. Chem. Phys., 13, 3619-3641, doi:10.5194/acp-13-3619-2013, 2013.

Ko, M., Newman, P., Reimann, S., and Strahan, S. (Eds.): Lifetimes of stratospheric ozone-depleting substances, their replacements, and related species, SPARC Report No. 6, WCRP-15/2013, 2013.

Konopka, P. and Pan, L. L.: On the mixing-driven formation of the Extratropical Transition Layer (ExTL), J. Geophys. Res., 117, D18301, doi:10.1029/2012JD017876, 2012.

Konopka, P., Steinhorst, H.-M., Grooß, J.-U., Günther, G., Müller, R., Elkins, J. W., Jost, H.-J., Richard, E., Schmidt, U., Toon, G., and McKenna, D. S.: Mixing and ozone loss in the 1999-2000 Arctic vortex: simulations with the 3-dimensional Chemical Lagrangian Model of the Stratosphere (CLaMS), J. Geophys. Res., 109, D02315, doi:10.1029/2003JD003792, 2004.

Konopka, P., Günther, G., McKenna, D. S., Müller, R., Offermann, D., Spang, R., and Riese, M.: How homogeneous and isotropic is stratospheric mixing? Comparison of CRISTA-1 observations with transport studies based on the Chemical Lagrangian Model of the Stratosphere (CLaMS), Q. J. Roy. Meteor. Soc., 131, 565-579, doi:10.1256/qj.04.47, 2005.

Konopka, P., Günther, G., Müller, R., dos Santos, F. H. S., Schiller, C., Ravegnani, F., Ulanovsky, A., Schlager, H., Volk, C. M., Viciani, S., Pan, L. L., McKenna, D.-S., and Riese, M.: Contribution of mixing to upward transport across the tropical tropopause layer (TTL), Atmos. Chem. Phys., 7, 32853308, doi:10.5194/acp-7-3285-2007, 2007.

Konopka, P., Grooß, J.-U., Günther, G., Ploeger, F., Pommrich, R., Müller, R., and Livesey, N.: Annual cycle of ozone at and above the tropical tropopause: observations versus simulations with the Chemical Lagrangian Model of the Stratosphere (CLaMS), Atmos. Chem. Phys., 10, 121-132, doi:10.5194/acp-10-121-2010, 2010.

Konopka, P., Ploeger, F., and Müller, R.: Entropy- and static stability-based Lagrangian model grids, in: Geophysical Monograph Series: Lagrangian Modeling of the Atmosphere, edited by: Lin, J., Vol. 200, American Geophysical Union, 99-109, doi:10.1029/2012GM001253, 2012.

Kumar, R., Naja, M., Pfister, G. G., Barth, M. C., and Brasseur, G. P.: Source attribution of carbon monoxide in India and surrounding regions during wintertime, J. Geophys. Res., 118, 1981-1995, doi:10.1002/jgrd.50134, 2013.

Liu, C., Zipser, E., Garrett, T., Jiang, J. H., and Su, H.: How do the water vapor and carbon monoxide "tape recorder" start near the tropical tropopause?, Geophys. Res. Lett., 34, L09804, doi:10.1029/2006GL029234, 2007.

Liu, J., Logan, J. A., Murray, L. T., Pumphrey, H. C., Schwartz, M. J., and Megretskaia, I. A.: Transport analysis and source attribution of seasonal and interannual variability of $\mathrm{CO}$ in the tropical upper troposphere and lower stratosphere, Atmos. Chem. Phys., 13, 129-146, doi:10.5194/acp-13-129-2013, 2013.
Livesey, N. J., Snyder, W. V., Read, W. G., and Wagner, P.: Retrieval algorithms for the EOS Microwave Limb Sounder (MLS) instrument, IEEE T. Geosci. Remote, 44, 1144-1155, 2006.

Livesey, N. J., Filipiak, M. J., Froidevaux, L., Read, W. G., Lambert, A., Santee, M. L., Jiang, J. H., Pumphrey, H. C., Waters, J. W., Cofield, R. E., Cuddy, D. T., Daffer, W. H., Drouin, B. J., Fuller, R. A., Jarnot, R. F., Jiang, Y. B., Knosp, B. W., Li, Q. B., Perun, V. S., Schwartz, M. J., Snyder, W. V., Stek, P. C., Thurstans, R. P., Wagner, P. A., Avery, M., Browell, E. V., Cammas, J.-P., Christensen, L. E., Diskin, G. S., Gao, R.-S., Jost, H.-J., Loewenstein, M., Lopez, J. D., Nedelec, P., Osterman, G. B., Sachse, G. W., and Webster, C. R.: Validation of Aura Microwave Limb Sounder $\mathrm{O}_{3}$ and $\mathrm{CO}$ observations in the upper troposphere and lower stratosphere, J. Geophys. Res., 113, D15S02, doi:10.1029/2007JD008805, 2008.

Livesey, N. J., Read, W. G., Froidevaux, L., Lambert, A., Manney, G. L., Pumphrey, H. C., Santee, M. L., Schwartz, M. J., Wang, S., Cofield, R. E., Cuddy, D. T., Fuller, R. A., Jarnot, R. F., Jiang, J. H., Knosp, B. W., Stek, P. C., Wagner, P. A., and Wu, D. L.: EOS MLS Version 3.3 Level 2 data quality and description document, Tech. rep., Jet Propulsion Laboratory, available from: http://mls.jpl.nasa.gov/data/v3-3_data_quality_ document.pdf (last access: 6 August 2014), 2011.

Luo, M., Rinsland, C. P., Rodgers, C. D., Logan, J. A., Worden, H., Kulawik, S., Eldering, A., Goldman, A., Shephard, M. W., Gunson, M., and Lampel, M.: Comparison of carbon monoxide measurements by TES and MOPITT: influence of a priori data and instrument characteristics on nadir atmospheric species retrieval, J. Geophys. Res., 112, D09303, doi:10.1029/2006JD007663, 2007.

Mahowald, N. M., Plumb, R. A., Rasch, P. J., del Corral, J., and Sassi, F.: Stratospheric transport in a three-dimensional isentropic coordinate model, J. Geophys. Res., 107, 4254, doi:10.1029/2001JD001313, 2002.

Masarie, K. and Tans, P.: Extension and integration of atmospheric carbon dioxide data into a globally consistent measurement record, J. Geophys. Res., 100, 11593-11610, 1995.

McKenna, D. S., Grooß, J.-U., Günther, G., Konopka, P., Müller, R., Carver, G., and Sasano, Y.: A new Chemical Lagrangian Model of the Stratosphere (CLaMS): 2. Formulation of chemistry scheme and initialization, J. Geophys. Res., 107, 4256, doi:10.1029/2000JD000113, 2002a.

McKenna, D. S., Konopka, P., Grooß, J.-U., Günther, G., Müller, R., Spang, R., Offermann, D., and Orsolini, Y.: A new Chemical Lagrangian Model of the Stratosphere (CLaMS): 1. Formulation of advection and mixing, J. Geophys. Res., 107, 4309, doi:10.1029/2000JD000114, 2002b.

Minschwaner, K., Hoffmann, L., Brown, A., Riese, M., Müller, R., and Bernath, P. F.: Stratospheric loss and atmospheric lifetimes of CFC-11 and CFC-12 derived from satellite observations, Atmos. Chem. Phys., 13, 4253-4263, doi:10.5194/acp-13-42532013, 2013.

Montzka, S.: Source gases that affect stratospheric ozone, in: Stratospheric Ozone Depletion and Climate Change, edited by: Müller, R., The Royal Society of Chemistry, 33-77, 2012.

Montzka, S. A., Butler, J. H., Myers, R. C., Thompson, T. M., Swanson, T. H., Clarke, A. D., Lock, L. T., and Elkins, J. W.: Decline in the tropospheric abundance of halogen from halocarbons: im- 
plications for stratospheric ozone depletion, Science, 272, 13181322, 1996.

Morgenstern, O., Braesicke, P., O'Connor, F. M., Bushell, A. C., Johnson, C. E., Osprey, S. M., and Pyle, J. A.: Evaluation of the new UKCA climate-composition model - Part 1: The stratosphere, Geosci. Model Dev., 2, 43-57, doi:10.5194/gmd-2-432009, 2009.

Morgenstern, O., Zeng, G., Luke Abraham, N., Telford, P. J., Braesicke, P., Pyle, J. A., Hardiman, S. C., O'Connor, F. M., and Johnson, C. E.: Impacts of climate change, ozone recovery, and increasing methane on surface ozone and the tropospheric oxidizing capacity, J. Geophys. Res., 118, 1028-1041, doi:10.1029/2012JD018382, 2013.

Mote, P. W., Rosenlof, K. H., McIntyre, M. E., Carr, E. S., Gille, J. G., Holton, J. R., Kinnersley, J. S., Pumphrey, H. C., Russell III, J. M., and Waters, J. W.: An atmospheric tape recorder: the imprint of tropical tropopause temperatures on stratospheric water vapor, J. Geophys. Res., 101, 3989-4006, 1996.

Nivano, M., Yamazaki, K., and Shiotani, M.: Seasonal and QBO variations of ascent rate in the tropical lower stratosphere as inferred from UARS HALOE trace gas data, J. Geophys. Res., 108, 4794, doi:10.1029/2003JD003871, 2003.

Novelli, P. C., Masarie, K. A., Lang, P. M., Hall, B. D., Myers, R. C., and Elkins, J. W.: Reanalysis of tropospheric CO trends: effects of the 1997-1998 wildfires, J. Geophys. Res., 108, 4464, doi:10.1029/2002JD003031, 2003.

Pan, L. L., Konopka, P., and Browell, E. V.: Observations and model simulations of mixing near the extratropical tropopause, J. Geophys. Res., 111, D05106, doi:10.1029/2005JD006480, 2006.

Park, M., Randel, W. J., Gettelman, A., Massie, S. T., and Jiang, J. H.: Transport above the Asian summer monsoon anticyclone inferred from Aura Microwave Limb Sounder tracers, J. Geophys. Res., 112, D16309, doi:10.1029/2006JD008294, 2007.

Park, M., Randel, W. J., Emmons, L. K., Bernath, P. F., Walker, K. A., and Boone, C. D.: Chemical isolation in the Asian monsoon anticyclone observed in Atmospheric Chemistry Experiment (ACE-FTS) data, Atmos. Chem. Phys., 8, 757-764, doi:10.5194/acp-8-757-2008, 2008.

Park, M., Randel, W. J., Emmons, L. K., and Livesey, N. J.: Transport pathways of carbon monoxide in the Asian summer monsoon diagnosed from Model of Ozone and Related Tracers (MOZART), J. Geophys. Res., 114, D08303, doi:10.1029/2008JD010621, 2009.

Pfister, G., Pétron, G., Emmons, L. K., Gille, J. C., Edwards, D. P., Lamarque, J.-F., Attie, J.-L., Granier, C., and Novelli, P. C.: Evaluation of CO simulations and the analysis of the CO budget for Europe, J. Geophys. Res., 109, D19304, doi:10.1029/2004JD004691, 2004.

Phillips, M. P., Sievers, R. E., Goldan, P. D., Kuster, W. C., and Fehsenfeld, F. C.: Enhancement of electron capture detector sensitivity to nonelectron attaching compounds by addition of nitrous oxide to the carrier gas, Anal. Chem., 51, 1819-1825, 1979.

Ploeger, F., Fueglistaler, S., Grooß, J.-U., Günther, G., Konopka, P., Liu, Y. S., Müller, R., Ravegnani, F., Schiller, C., Ulanovski, A., and Riese, M.: Insight from ozone and water vapour on transport in the tropical tropopause layer (TTL), Atmos. Chem. Phys., 11, 407-419, doi:10.5194/acp-11-407-2011, 2011.
Ploeger, F., Konopka, P., Müller, R., Fueglistaler, S., Schmidt, T., Manners, J. C., Grooß, J.-U., Günther, G., Forster, P. M., and Riese, M.: Horizontal transport affecting trace gas seasonality in the Tropical Tropopause Layer (TTL), J. Geophys. Res., 117, D09303, doi:10.1029/2011JD017267, 2012a.

Ploeger, F., Konopka, P., Müller, R., Günther, G., Grooß, J.-U., Schiller, C., Ravegnani, F., Ulanovski, A., and Riese, M.: Backtrajectory reconstruction of water vapour and ozone in-situ observations in the TTL, Meteorol. Z., 21, 239-244, 2012b.

Ploeger, F., Günther, G., Konopka, P., Fueglistaler, S., Müller, R., Hoppe, C., Kunz, A., Spang, R., Grooß, J.-U., and Riese, M.: Horizontal water vapor transport in the lower stratosphere from subtropics to high latitudes during boreal summer, J. Geophys. Res., 118, 8111-8127, doi:10.1002/jgrd.50636, 2013.

Pommrich, R., Müller, R., Grooß, J.-U., Günther, G., Konopka, P., Riese, M., Heil, A., Schultz, M., Pumphrey, H.-C., and Walker, K. A.: What causes the irregular cycle of the atmospheric tape recorder signal in HCN?, Geophys. Res. Lett., 37, L16805, doi:10.1029/2010GL044056, 2010.

Pommrich, R., Müller, R., Grooß, J.-U., Konopka, P., Günther, G., Pumphrey, H.-C., Viciani, S., D'Amato, F., and Riese, M.: Carbon monoxide as a tracer for tropical troposphere to stratosphere transport in the Chemical Lagrangian Model of the Stratosphere (CLaMS), Geosci. Model Dev. Discuss., 4, 1185-1211, doi:10.5194/gmdd-4-1185-2011, 2011.

Pumphrey, H. C., Filipiak, M. J., Livesey, N. J., Schwartz, M. J., Boone, C., Walker, K. A., Bernath, P., Ricaud, P., Barret, B., Clerbaux, C., Jarnot, R. F., Manney, G. L., and Waters, J. W.: Validation of middle-atmosphere carbon monoxide retrievals from MLS on Aura, J. Geophys. Res., 112, D24S38, doi:10.1029/2007JD008723, 2007.

Pumphrey, H. C., Boone, C., Walker, K. A., Bernath, P., and Livesey, N. J.: Tropical tape recorder observed in HCN, Geophys. Res. Lett., 35, L05801, doi:10.1029/2007GL032137, 2008.

Punge, H. J., Konopka, P., Giorgetta, M. A., and Müller, R.: Effects of the quasi-biennial oscillation on low-latitude transport in the stratosphere derived from trajectory calculations, J. Geophys. Res., 114, D03102, doi:10.1029/2008JD010518, 2009.

Randel, W. and Jensen, E.: Physical processes in the tropical tropopause layer and their role in a changing climate, Nat. Geosci., 6, 169-176, doi:10.1038/ngeo1733, 2013.

Randel, W. J., Wu, F., Russell, J. M., Roche, A., and Waters, J. W. Seasonal cycles and QBO variations in stratospheric $\mathrm{CH}_{4}$ and $\mathrm{H}_{2} \mathrm{O}$ observed in UARS HALOE data, J. Atmos. Sci., 55, 163 $185,1998$.

Randel, W. J., Park, M., Wu, F., and Livesey, N.: A large annual cycle in ozone above the tropical tropopause linked to the BrewerDobson circulation, J. Atmos. Sci., 64, 4479-4488, 2007.

Ribera, P., Penã-Ortiz, C., Garcia-Herrera, R., Gallego, D., Gimeno, L., and Hernández, E.: Detection of the secondary meridional circulation associated with the quasibiennial oscillation, J. Geophys. Res., 109, D18112, doi:10.1029/2003JD004363, 2004.

Ricaud, P., Barret, B., Attié, J.-L., Motte, E., Le Flochmoën, E., Teyssèdre, H., Peuch, V.-H., Livesey, N., Lambert, A., and Pommereau, J.-P.: Impact of land convection on tropospherestratosphere exchange in the tropics, Atmos. Chem. Phys., 7, 5639-5657, doi:10.5194/acp-7-5639-2007, 2007. 
Riese, M., Ploeger, F., Rap, A., Vogel, B., Konopka, P., Dameris, M., and Forster, P.: Impact of uncertainties in atmospheric mixing on simulated UTLS composition and related radiative effects, J. Geophys. Res., 117, D16305, doi:10.1029/2012JD017751, 2012.

Rigby, M., Prinn, R. G., O’Doherty, S., Montzka, S. A., McCulloch, A., Harth, C. M., Mühle, J., Salameh, P. K., Weiss, R. F., Young, D., Simmonds, P. G., Hall, B. D., Dutton, G. S., Nance, D., Mondeel, D. J., Elkins, J. W., Krummel, P. B., Steele, L. P., and Fraser, P. J.: Re-evaluation of the lifetimes of the major $\mathrm{CFCs}$ and $\mathrm{CH}_{3} \mathrm{CCl}_{3}$ using atmospheric trends, Atmos. Chem. Phys., 13, 2691-2702, doi:10.5194/acp-13-26912013, 2013.

Roiger, A., Schlager, H., Schäfler, A., Huntrieser, H., Scheibe, M., Aufmhoff, H., Cooper, O. R., Sodemann, H., Stohl, A., Burkhart, J., Lazzara, M., Schiller, C., Law, K. S., and Arnold, F.: Insitu observation of Asian pollution transported into the Arctic lowermost stratosphere, Atmos. Chem. Phys., 11, 10975-10994, doi:10.5194/acp-11-10975-2011, 2011.

Rosenlof, K. H.: Seasonal cycle of the residual mean meridional circulation in the stratosphere, J. Geophys. Res., 100, 5173-5191, 1995.

Sander, S. P., Friedl, R. R., Golden, D. M., Kurylo, M. J., Huie, R. E., Orkin, V. L., Moortgat, G. K., Ravishankara, A. R., Kolb, C. E., Molina, M. J., and Finlayson-Pitts, B. J.: Chemical kinetics and photochemical data for use in stratospheric studies, JPL Publication 02-25, 2002.

Sander, S. P., Friedl, R. R., Golden, D. M., Kurylo, M. J., Moortgat, G. K., Keller-Rudek, H., Wine, P. H., Ravishankara, A. R., Kolb, C. E., Molina, M. J., Finlayson-Pitts, B. J., Huie, R. E., and Orkin, V. L.: Chemical kinetics and photochemical data for use in atmospheric studies, JPL Publication 06-2, 2006.

Sander, S. P., Friedl, R. R., Barker, J. R., Golden, D. M., Kurylo, M. J., Wine, P. H., Abbatt, J. P. D., Burkholder, J. B., Kolb, C. E., Moortgat, G. K., Huie, R. E., and Orkin, V. L.: Chemical kinetics and photochemical data for use in atmospheric studies, JPL Publication 10-6, 2011.

Schoeberl, M. R., Kawa, S. R., Douglass, A. R., Waters, J., Livesey, N., Read, W., and Filipiak, M.: The carbon monoxide tape recorder, Geophys. Res. Lett., 33, L12811, doi:10.1029/2006GL026178, 2006.

Schoeberl, M. R., Douglass, A. R., Newman, P. A., Lait, L. R., Lary, D., Waters, J., Livesey, N., Froidevaux, L., Lambert, A., Read, W., Filipiak, M. J., and Pumphrey, H. C.: QBO and annual cycle variations in tropical lower stratosphere trace gases from HALOE and Aura MLS observations, J. Geophys. Res., 113, D05301, doi:10.1029/2007JD008678, 2008.

Schoeberl, M. R., Dessler, A. E., and Wang, T.: Simulation of stratospheric water vapor and trends using three reanalyses, Atmos. Chem. Phys., 12, 6475-6487, doi:10.5194/acp-12-6475-2012, 2012

Schultz, M. G., Heil, A., Hoelzemann, J. J., Spessa, A., Thonicke, K., Goldammer, J. G., Held, A. C., Pereira, J. M. C., and van het Bolscher, M.: Global wildland fire emissions from 1960 to 2000, Global Biogeochem. Cy., 22, GB2002, doi:10.1029/2007GB003031, 2008.

Spang, R., Günther, G., Riese, M., Hoffmann, L., Müller, R., and Griessbach, S.: Satellite observations of cirrus clouds in the Northern Hemisphere lowermost stratosphere, Atmos. Chem.
Phys. Discuss., 14, 12323-12375, doi:10.5194/acpd-14-123232014, 2014.

Srivastava, S. and Sheel, V.: Study of tropospheric CO and $\mathrm{O}_{3}$ enhancement episode over Indonesia during Autumn 2006 using the Model for Ozone and Related chemical Tracers (MOZART-4), Atmos. Environ., 67, 53-62, doi:10.1016/j.atmosenv.2012.09.067, 2013.

Stiller, G. P., von Clarmann, T., Höpfner, M., Glatthor, N., Grabowski, U., Kellmann, S., Kleinert, A., Linden, A., Milz, M., Reddmann, T., Steck, T., Fischer, H., Funke, B., LópezPuertas, M., and Engel, A.: Global distribution of mean age of stratospheric air from MIPAS SF 6 measurements, Atmos. Chem. Phys., 8, 677-695, doi:10.5194/acp-8-677-2008, 2008.

Viciani, S., D’Amato, F., Mazzinghi, P., Castagnoli, F., Toci, G., and Werle, P.: A cryogenically operated laser diode spectrometer for airborne measurement of stratospheric trace gases, Appl. Phys B, 90, 581-592, doi:10.1007/s00340-007-2885-2, 2008.

Vogel, B., Pan, L. L., Konopka, P., Günther, G., Müller, R., Hall, W., Campos, T., Pollack, I., Weinheimer, A., Wei, J., Atlas, E. L., and Bowman, K. P.: Transport pathways and signatures of mixing in the extratropical tropopause region derived from Lagrangian model simulations, J. Geophys. Res., 116, D05306, doi:10.1029/2010JD014876, 2011.

Vogel, B., Günther, G., Müller, R., Grooß, J.-U., Hoor, P., Krämer, M., Müller, S., Zahn, A., and Riese, M.: Fast transport from Southeast Asia boundary layer sources to northern Europe: rapid uplift in typhoons and eastward eddy shedding of the Asian monsoon anticyclone, Atmos. Chem. Phys., 14, 12745-12762, doi:10.5194/acp-14-12745-2014, 2014.

Volk, C. M., Elkins, J. W., Fahey, D. W., Salawitch, R. J., Dutton, G. S., Gilligan, J. M., Proffitt, M. H., Loewenstein, M., Podolske, J. R., Minschwaner, K., Margitan, J. J., and Chan, K. R.: Quantifying transport between the tropical and mid-latitude lower stratosphere, Science, 272, 1763-1768, 1996.

Volk, C. M., Elkins, J. W., Fahey, D. W., Dutton, G. S., Gilligan, J. M., Loewenstein, M., Podolske, J. R., and Chan, K. R.: On the evaluation of source gas lifetimes from stratospheric observations, J. Geophys. Res., 102, 25543-25564, 1997.

Volk, C., Riediger, O., Strunk, M., Schmidt, U., Ravegnani, F., Ulanovsky, A., and Rudakovand, V.: In situ tracer measurements in the tropical tropopause region during APE-THESEO, in: Eur. Comm. Air Pollut. Res. Report, Vol. 73, 661-664, 2000.

Wang, T., Randel, W. J., Dessler, A. E., Schoeberl, M. R., and Kinnison, D. E.: Trajectory model simulations of ozone $\left(\mathrm{O}_{3}\right)$ and carbon monoxide $(\mathrm{CO})$ in the lower stratosphere, Atmos. Chem. Phys., 14, 7135-7147, doi:10.5194/acp-14-7135-2014, 2014.

Waters, J. W., Froidevaux, L., Harwood, R. S., Jarnot, R. F., Pickett, H. M., Read, W. G., Siegel, P. H., Cofield, R. E., Filipiak, M. J., Flower, D. A., Holden, J. R., Lau, G. K., Livesey, N. J., Manney, G. L., Pumphrey, H. C., Santee, M. L., Wu, D. L., Cuddy, D. T., Lay, R. R., Loo, M. S., Perun, V. S., Schwartz, M. J., Stek, P. C., Thurstans, R. P., Boyles, M. A., Chandra, S., Chavez, M. C., Chen, G.-S., Chudasama, B. V., Dodge, R., Fuller, R. A., Girard, M. A., Jiang, J. H., Jiang, Y., Knosp, B. W., LaBelle, R. C., Lam, J. C., Lee, K. A., Miller, D., Oswald, J. E., Patel, N. C., Pukala, D. M., Quintero, O., Scaff, D. M., Snyder, W. V., Tope, M. C., Wagner, P. A., and Walch, M. J.: The Earth Observing System Microwave Limb 
Sounder (EOS MLS) on the Aura satellite, IEEE T. Geosci. Remote, 44, 1106-1121, 2006.

Waugh, D. W. and Hall, T. M.: Age of stratospheric air: theory, observations, and models, Rev. Geophys., 40, 1-27, 2002.

Wegner, T., Grooß, J.-U., von Hobe, M., Stroh, F., SumińskaEbersoldt, O., Volk, C. M., Hösen, E., Mitev, V., Shur, G., and Müller, R.: Heterogeneous chlorine activation on stratospheric aerosols and clouds in the Arctic polar vortex, Atmos. Chem. Phys., 12, 11095-11106, doi:10.5194/acp-12-110952012, 2012.
WMO: Scientific assessment of ozone depletion: 2010, Global Ozone Research and Monitoring Project-Report No. 52, Geneva, Switzerland, 2011.

Wright, J. S. and Fueglistaler, S.: Large differences in reanalyses of diabatic heating in the tropical upper troposphere and lower stratosphere, Atmos. Chem. Phys., 13, 9565-9576, doi:10.5194/acp-13-9565-2013, 2013. 